Conferência Internacional do Trabalho

Simulação em Ambiente Universitário

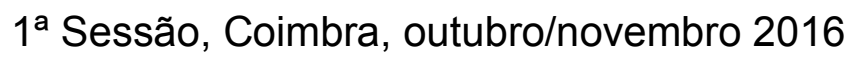

\title{
Dia 1
}

\section{Primeira Sessão Plenária da CIT}

Quinta-feira, 20 de outubro de 2016, 10h30

\section{Abertura da Sessão}

\begin{tabular}{l}
\hline JOÃO MAIA (Secretário-Geral da \\
Conferência Internacional do Trabalho)
\end{tabular}

Na minha qualidade como Secretário-geral da Conferência Internacional do Trabalho, é uma honra e um privilégio declarar aberta a sessão plenária inaugural dos trabalhos da Conferência. Quero aproveitar a oportunidade para vos desejar a todos umas boas-vindas a Coimbra e, em particular, à Universidade de Coimbra.

Esta Conferência Internacional do Trabalho desenvolve-se segundo o tema "O futuro do trabalho".

Vivemos um tempo em que, um pouco por todo mundo, se tentam ultrapassar os efeitos restantes da crise financeira, económica e social internacional iniciada em 2008. Em paralelo, assistimos a um quadro de globalização, que nos seus vários níveis, não dá sinais de abrandamento. Tal cenário confronta-nos com questões e dilemas sobre a preservação da coesão social, sobre a promoção da competitividade económica, mas também sobre a sustentabilidade dos ecossistemas.

Como poderão verificar o agendamento dos temas desta Conferência refletirá estas preocupações. Os temas que irão ser discutidos são todos de uma importância crítica para o mundo do trabalho e não haverá dúvidas de que esta Conferência estará à altura das expetativas que lhe são depositadas.

\section{Eleição do Presidente e Vice-Presidentes da Conferência}

JOÃO MAIA (Secretário-Geral da
Conferência Internacional do Trabalho)

Pelos poderes que me foram confiados, passo a apresentar os membros da estrutura da Conferência.

Como Presidente, em representação do grupo dos governantes, Doutoranda Joana Ricarte. A Doutoranda Joana Ricarte é historiadora pela Universidade de Brasília e mestre em Relações Internacionais com especialização em Estudos da Paz e Segurança pela Faculdade de Economia da Universidade de Coimbra. Atualmente está a desenvolver sua tese de doutoramento em Política Internacional e Resolução de Conflitos, nos Centro de Estudos Sociais e Faculdade de Economia da Universidade de Coimbra, sobre o papel dos movimentos sociais para a construção da paz em Israel e na Palestina. 
Como Vice-Presidente, indicado pelo grupo dos empregadores, Doutor Nuno Teles. O Doutor Nuno Teles é investigador pósdoutoral no Centro de Estudos Sociais da Universidade de Coimbra e doutorado em Economia pela School of Oriental and African Studies (SOAS), da Universidade de Londres. Os seus interesses em investigação centram-se na área da economia política e da financeirização, sendo um dos autores do livro Eurozone in Crisis (Verso, 2012) e mais recentemente "A financeirização do capitalismo em Portugal" (Actual, 2016), com João Rodrigues e Ana Cordeiro Santos.

E, como Vice-Presidente, indicado pelo grupo dos trabalhadores, Doutorando Alfredo Campos. O Doutorando Alfredo Campos é Investigador Júnior do Centro de Estudos Sociais da Universidade de Coimbra. É licenciado em Sociologia pela Faculdade de Economia da Universidade de Coimbra, na especialidade de Sociologia do Trabalho e do Emprego. É Mestre em Relações de Trabalho, Desigualdades Sociais e Sindicalismo, pela mesma instituição. Atualmente, é doutorando do Programa de Doutoramento Human Rights in Contemporary Societies, do Centro de Estudos Sociais e do Instituto de Investigação Interdisciplinar da Universidade de Coimbra.

Nesta sequência, assume a condução dos trabalhos a Excelentíssima Sra. Presidente Joana Ricarte.

Excelentíssima Sra. Presidente a condução dos trabalhos da Conferência está nas suas mãos,

Muito obrigado e bom trabalho.

\section{Discurso Presidencial}

A Presidente

Muito obrigada Senhor Secretário Geral; Excelentíssimo Senhor Diretor-Geral da Organização Internacional do Trabalho, Guy Ryder; Secretários da Conferência; Vossas
Excelências; Senhoras e Senhores. Deixei propositadamente para o fim destes cumprimentos iniciais aqueles que são, na verdade, os grandes protagonistas desta Conferência: os senhores e senhoras delegados mandantes tripartidos representantes dos governos, dos trabalhadores e dos empregadores. Saúdo-os de modo muito especial estando consciente de que é com os contributos de todos e de todas que a discussão sobre o futuro do trabalho sairá mais engrandecida.

É para mim uma grande honra poder presidir à sessão plenária da Conferência da Organização Internacional do Trabalho. Quero aproveitar para desejar a todos e a todas calorosas boas vindas à Universidade de Coimbra e a todos os que vêm de fora, nomeadamente o Senhor Diretor-Geral da OIT, as boas vindas a este acolhedor país, que é Portugal.

Como Presidente desta Sessão Plenária de Abertura gostaria de falar brevemente sobre os objetivos que espero que sejam alcançados nesta Conferência. Conforme apontado pelo Senhor Diretor-Geral em seu ambicioso relatório sobre o Futuro do Trabalho - que inicia um processo de reflexão profunda sobre esta temática com foco nas questões da dignidade e igualdade no trabalho, do futuro do emprego e da proteção social -, o mundo do trabalho vem sendo transformado pelas mudanças em curso cuja rapidez e abrangência tornam urgente uma reação por parte da OIT, de forma a poder fazer avançar a causa da justiça social. O aumento dos índices de desemprego, principalmente entre a população jovem; a perseverança dos desequilíbrios anacrónicos nas condições e ofertas de trabalho no que concerne aos homens e às mulheres; as desigualdades sociais, o nível de pobreza e as baixas taxas de proteção social sobretudo em países em desenvolvimento mas igualmente 
preocupantes nos países industrializados, cada vez mais confrontados com problemas de sustentabilidade e adaptação; e os persistentes e deploráveis relatos de centenas de milhares de crianças que, ao invés de estudarem, estão a trabalhar; e mais outras milhares de vítimas de trabalho forçado pelo mundo afora, representam os maiores desafios ao respeito universal pelos princípios e direitos fundamentais no trabalho dos quais a OIT é grande defensora.

Mais particularmente, sendo este encontro realizado em Portugal, parece-me essencial aproveitar este momento para recordar $o$ contexto no qual estamos inseridos, com a expectativa de vê-lo refletido na Resolução final desta Conferência. $\mathrm{O}$ ajustamento estrutural a que Portugal foi sujeito nos últimos anos agravou consideravelmente as condições laborais no país. A liberalização do mercado de trabalho, ao invés de promover o desenvolvimento económico e a criação de emprego, contribuiu principalmente para a precarização das condições laborais. Os salários médios decaíram consideravelmente e a proporção dos trabalhadores que auferem o salário mínimo aumentou. A remuneração do trabalho qualificado decaiu abruptamente. Milhares de recém-licenciados, mestres e doutores, assim como trabalhadores das mais diversas áreas, emigraram, debilitando o tecido produtivo português. As políticas ativas de emprego, promovidas num quadro neoliberal de auto-emprego e empreendedorismo forçado, foram, globalmente, infrutíferas. Casos de sucesso no tecido empresarial português, principalmente nas PME's exportadoras, devem-se mais à aposta na contratação de mão de obra qualificada, investimento em inovação e adopção de novas estratégias de gestão, do que na atribuição de subsídios para a criação de micro-negócios e o auto-emprego. Por fim, é necessário, para Portugal reabilitar a imagem dos trabalhadores do setor público, sobre os quais recaíram culpas injustificadas. A crise do sistema financeiro afetou primordialmente aqueles que vivem do rendimento do seu trabalho.

É verdade que vivemos num mundo globalizado, que enfrenta desafios adversos como o agravamento das desigualdades, as crescentes taxas de desemprego ou formas de subemprego. Mas, ao mesmo tempo, é um mundo de oportunidades que decorrem de um extraordinário crescimento das capacidades de produção à escala mundial, que nos provém hoje de mecanismos e meios materiais para eliminar a pobreza. Ora, nesse contexto parece ser essencial integrar as diversas contribuições dos mandantes tripartidos, mas também das organizações internacionais, dos institutos de investigação, das universidades, da sociedade civil e dos indivíduos. É a este repto que esta Conferência deve responder, com os contributos dos jovens delegados e delegadas, que esperemos que sejam capazes de juntar forças, orientados para o desenvolvimento de ações concretas, ao serviço da causa da justiça social e da dignidade no trabalho, assinalando, assim, os objetivos e valores desta Organização e seus anseios para os anos que seguirão ao centenário.

Muito obrigada.

\section{Discursos Vice-Presidenciais}

A Presidente

Antes de prosseguir com os demais discursos da ordem de trabalhos, permitam-me cumprimentar todos os que empenharam-se na organização desta Conferência, principalmente os meus colegas da equipa de facilitadores que estão atuando como Secretários e Oficiais desta Conferência, que tanto trabalharam para que esta fosse um sucesso, os Excelentíssimos Senhores e 
Senhoras Alfredo Campos, Ana Alves da Silva, Andreia Santos, Beatriz Caitana, Dora Fonseca, João Maia, Marina Henriques, Nuno Teles, Sandra Graça, Saulo Aristides, Teresa Maneca Lima e Vanda Amaro Dias. Tem sido um imenso prazer fazer parte desta equipa e aprender convosco.

Passo agora a palavra ao Excelentíssimo Senhor Vice-Presidente representante do grupo dos Empregadores, o Senhor Nuno Teles. O Senhor tem a palavra por 3 minutos.

O Vice-Presidente (representante do grupo dos Empregadores)

Muito Obrigado, Excelentíssima Senhora Presidente. Começo por saudar o Excelentíssimo Diretor-Geral da Organização Internacional do Trabalho, o Excelentíssimo Secretário da Conferência e os Excelentíssimos delegados. E uma honra participar nesta Conferência Internacional do Trabalho na qualidade de Vice-Presidente nomeado pelos Empregadores aqui presentes.

Esta conferência Internacional do Trabalho, dedicada ao tema do "Futuro do Trabalho" é uma oportunidade única de reflexão, já que beneficiamos da organização tripartida da Organização Internacional do Trabalho, onde governos, trabalhadores $\mathrm{e}$ empregadores podem contribuir e dialogar. As diferentes perspetivas aqui presentes são essenciais para um diálogo frutuoso donde se retirem conclusões que possam promover o emprego e regular as relações de trabalho à escala internacional. Os empregadores são parte inescapável desta reflexão. Na nossa diversidade, produto das diferentes escalas empresariais e diferentes sectores que aqui representamos, podemos contribuir para soluções que redinamizem o crescimento e o emprego digno à escala internacional.

De facto, os desafios que se colocam a esta conferência sobre o futuro do trabalho são formidáveis. Vivemos hoje um momento histórico muito particular. Oito anos depois da mais grave crise económica internacional desde a Grande Depressão, continuamos num clima de baixo crescimento económico, procura deprimida, desequilíbrios macroeconómicos na esfera internacional e um sistema financeiro que não serve as necessidades de financiamento das empresas. $\mathrm{O}$ resultado está à vista: baixo investimento, número elevado de falências, taxas de desemprego elevadas, aumento das desigualdades e tensões políticas crescentes. Face a este cenário de estagnação secular que afeta as três partes aqui presentes, responder aos atuais desafios, perspetivando o papel futuro da OIT e o futuro do trabalho são cruciais para que consigamos alcançar os objetivos que sempre guiaram a OIT nos seus quase cem anos de vida.

Esta organização tem um papel particularmente importante no atual contexto de crescente internacionalização da produção. A integração económica internacional não deve resultar num clima de concorrência desleal entre empresas e trabalhadores de países diferentes, numa corrida para o fundo onde as vantagens competitivas de cada um sejam só o custo de trabalho ou a ausência de regulação ambiental. Sendo originário de um país, Portugal, com uma pequena economia aberta, sujeita a sucessivos choques externos recentes, que serve de "indicador avançado" dos desafios que se colocam a todos os países num futuro próximo, penso ser urgente a reflexão sobre a prossecução de "standards" internacionais que regulem, de forma homogénea, as relações de trabalho na esfera internacional. Só assim poderemos alcançar um mercado global onde as melhores empresas sejam, de facto, as mais eficientes nos seus processos de produção, inovação e organização, condição inelutável para a criação de emprego digno. Além disso, 
devemos pensar em mecanismos que permitam uma competição internacional saudável entre as grandes empresas multinacionais $\mathrm{e}$ as pequenas e médias empresas, prevalecentes em países como o meu, de forma a garantir condições de prosperidade e geração de emprego em todas as escalas empresariais.

Uma competição leal é crucial para um clima económico internacional, não só gerador de riqueza e emprego, mas também potenciador da redinamização, senão mesmo refundação, do diálogo social entre empregadores, trabalhadores e governos. Sublinhando assim a importância desta conferência, termino com os meus votos de um excelente trabalho a todos os delegados presentes.

Muito obrigado.

\begin{tabular}{l}
\hline A Presidente \\
\hline Muito obrigada, Senhor Vice-Presidente. \\
Passo agora a palavra ao Excelentíssimo \\
Senhor Vice-Presidente representante do \\
grupo dos Trabalhadores, o Senhor Alfredo \\
Campos. O Senhor tem a palavra por 3 \\
minutos.
\end{tabular}

O Vice-Presidente (representante do grupo dos Trabalhadores)

Gostaria de iniciar esta minha intervenção saudando a Presidente da Mesa desta Conferência; o Excelentíssimo Diretor-Geral da Organização Internacional do Trabalho, Guy Rider; e o Secretariado da Conferência. Apresento, igualmente, os meus cumprimentos às delegadas e aos delegados presentes. E também, em particular, uma entusiasta e fraterna saudação às e aos representantes dos trabalhadores que, enquanto vice-presidente, represento também.

Espero assumir com dignidade as funções de vice-presidente da sessão plenária desta
Conferência Internacional do Trabalho, em representação dos trabalhadores. A Conferência poderá contar comigo, e certamente com todas e todos os delegados representantes dos trabalhadores, para o seu sucesso. É nesta qualidade de vice-presidente e representante dos trabalhadores, que gostaria agora de endereçar algumas palavras a esta Conferência.

O "fator trabalho" atravessa tempos difíceis. Nunca tanto foi produzido, e com tão baixos custos, mas a desigualdade nos proveitos, não só se mantém como se aprofunda significativamente. À escala global, o fosso entre os países mais ricos e os mais pobres não dá sinais de ser ultrapassado. Os países pobres mantêm-se na pobreza, fruto da exploração das suas riquezas pelos países mais ricos. Ao nível europeu, os países do Centro e do Norte dominam os países do sul.

Como perceber, e como aceitar, que se produza cada vez mais e mais barato, mas que a jornada de trabalho não diminua? Como perceber, e como aceitar, que os lucros cresçam, mas não os salários? Como perceber, e como aceitar, que as novas tecnologias e a automatização, quer da indústria quer dos serviços, não sirvam para aumentar salários e reduzir horas de trabalho, mas somente para aumentar lucros e despedir trabalhadores? Como perceber, e como aceitar, que a uma cada vez maior participação das mulheres no mercado de trabalho corresponda a persistência de desigualdades nos seus salários e carreiras? Como perceber, e como aceitar, que as gerações mais jovens, as mais qualificadas de sempre, só possam sonhar com desemprego e precariedade? Como perceber, e como aceitar, que cada vez mais riqueza conviva com tanta pobreza? Como perceber, e como aceitar, enfim, que do trabalho da grande maioria beneficie apenas a uma pequena minoria? 
Não é difícil perceber. Percebe-se pelos fundamentos do nosso sistema económico e pela busca incessante de cada vez mais lucro, de monopolização e de desregulação. E percebe-se porque desta busca incessante do lucro, de produzir cada vez mais, inevitavelmente correspondem crises de sobreprodução e de queda do lucro. Crises sempre pagas pelos trabalhadores, com desemprego, quedas dos salários, pobreza, fome.

E se não é difícil perceber, é impossível aceitar. Os trabalhadores não se conformam, não se podem conformar, com este estado das coisas. Através das suas organizações representativas, através dos seus delegados aqui presentes, os trabalhadores exigem a garantia dos seus direitos, reivindicam uma verdadeira negociação, reclamam por uma real, efetiva e apertada regulação.

Nesta Conferência, com a sua organização tripartida, os trabalhadores estão prontos para se sentarem à mesa com Governos e empregadores, para procurar soluções. As delegadas e os delegados dos trabalhadores, aqui presentes, estão cientes que a Organização Internacional do Trabalho, e a sua Conferência, são um espaço por excelência para afirmar as suas posições e propostas, negociando com Governos e empregadores.

Termino saudando, uma vez mais, esta Conferência e todos os presentes.

\section{Apresentação do relatório "O Futuro do} Trabalho"

\section{A Presidente}

Muito obrigada, Senhor Vice-Presidente. Tenho a prazer de apresentar agora o décimo Diretor-Geral da Organização Internacional do Trabalho, o Excelentíssimo Senhor Guy Ryder, que muito nos honra com a sua presença.
Nascido em Liverpool, no Reino Unido, em 1956, Guy Ryder estudou Ciências Sociais e Políticas na Universidade de Cambridge e Estudos Latino-Americanos na Universidade de Liverpool. Ele é fluente em Francês e Espanhol, assim como na sua língua materna, o Inglês. Iniciou a sua carreira profissional em 1981 como assistente no Departamento Internacional do Congresso do Congresso de Sindicatos em Londres.

A partir de 1985, ele ocupou a posição de Secretário Geral da Federação Internacional de Empregados, de Técnicos e de Quadros (FIET) em Genebra.

Em 1988, Guy Ryder tornou-se Diretor adjunto e - a partir de 1993 - Diretor do escritório de Genebra da Confederação Internacional dos Sindicatos Livres (CISL).

Guy Ryder passou a fazer parte da Organização Internacional do Trabalho em 1998 como Diretor do Departamento para Atividades dos Trabalhadores e, a partir de 1999, como Diretor do Escritório do DiretorGeral. Foi durante este período que a Agenda para o Trabalho Decente da OIT foi lançada e ganhou o apoio da Comunidade Internacional.

Em 2002, ele foi nomeado Secretário Geral da CISL, liderando o processo de unificação mundial do movimento sindical internacional democrático. Ele foi o primeiro Secretário Geral eleito da Confederação Sindical Internacional (CSI), quando esta foi criada em 2006. Presidiu a delegações sindicais internacionais em reuniões de alto nível com as Nações Unidas, o Fundo Monetário Internacional, o Banco Mundial e com a Organização Mundial do Comércio e as Cimeiras de Líderes do G20.

Em Setembro de 2010, Guy Ryder retornou à OIT em Genebra como Diretor Executivo, responsável pelos padrões internacionais do trabalho e pelos princípios e direitos fundamentais do trabalho. Dentre outras atividades, ele supervisionou a 
aplicação de Convenções e Recomendações da OIT. Ele também encabeçou diversas missões de alto-nível da OIT para abordar uma série de questões relacionadas com os padrões de trabalho em países como o Bahrain, a Colômbia, as Fiji, a Geórgia, Grécia, Myanmar e Suazilândia.

Guy Ryder foi eleitor Diretor-Geral da OIT pelo Conselho de Administração da OIT em Maio de 2012 e assumiu suas funções no dia 1 de Outubro de 2012. Quando assumiu o cargo, comprometeu-se a posicionar a Organização como um ator determinante na tradução dos princípios em ações, garantindo que ela teria a capacidade de fazer uma grande diferença no quotidiano do trabalho das pessoas em todos os continentes. Para sustentar isto ele lançou um amplo processo de reforma orientado para assegurar a autoridade da OIT em questões dentro do seu mandato.

O Excelentíssimo Senhor Diretor-Geral fará a apresentação do seu relatório "O Futuro do Trabalho". Your Excellency, Mr. Director General, you have the floor.

(fala o Diretor-Geral da OIT)

\section{Discursos iniciais dos representantes da estrutura tripartida da CIT}

\footnotetext{
A Presidente

Muito obrigada, Senhor Diretor-Geral por esta instigante apresentação que muito contribuirá para o enriquecimento dos debates desta Conferência.

A Presidência tem agora a honra de dar início aos trabalhos desta sessão plenária de abertura convidando os mandantes tripartidos para se dirigirem à plenária com seus discursos em nome dos governos, das organizações de empregadores e de trabalhadores das quais fazem parte.
}

A Presidência solicita que a senhora delegada representante do grupo dos Governos, a Excelentíssima Senhora Mariana Antunes dirija-se à mesa para proferir o seu discurso em nome do seu grupo. Senhora delegada, a Senhora tem 3 minutos.

\section{MARIANA ANTUNES (em representação do grupo dos Governantes)}

Inicio a minha intervenção saudando, com muita honra o Exmo. Sr. Presidente da Conferência, o Exmo. Sr. Diretor-Geral da OIT, Exmos. Srs. Delegados, muito bom dia a todos.

Parafraseando o relatório "O futuro do trabalho", "a internacionalização dos mercados de trabalho manifesta-se igualmente na migração de um número cada vez maior de trabalhadores à procura de emprego em vários países." É aqui que me centro: no desafio da inclusão de trabalhadores migrantes e as suas consequências políticas, sociais e económicas.

Cientes da realidade económica, abraçada numa crise e onde é difícil encontrar políticas que sejam sinónimo de sustentabilidade económica, o Governo encontra-se, no que concerne ao problema suprarreferido, preocupado com a integração dos migrantes trabalhadores. Sendo que se impõe a pergunta de como criar emprego para todos e estando a justiça social em causa, estará, por exemplo, a Europa habilitada a criar postos de trabalho para todos os migrantes e refugiados?

Perturba também a ideia de que "alguns países excluem os trabalhadores migrantes dos regimes de segurança social", segundo dados revelados pelo relatório global: "Igualdade no trabalho: Um desafio". No seguimento da Declaração sobre os Princípios e Direitos Fundamentais no Trabalho - que considera que se deve prestar especial atenção aos problemas de pessoas com necessidades especiais, como os trabalhadores migrantes - é 
nosso dever garantir direitos a todos estes. Não esquecendo os princípios estabelecidos pela Declaração da OIT sobre Justiça Social para uma Globalização Justa, impõe-se que todos os Membros da Organização prossigam com políticas que possibilitem e garantam o emprego, a proteção social, o diálogo social e os direitos no trabalho.

Para além ser de essencial relevância assegurar a todos os trabalhadores migrantes o acesso ao emprego e a políticas sociais, permitindo assegurar-lhes identidade, segurança material e inclusão social, é perentório que as condições de trabalho sejam dignas e as condições de inclusão social contribuam para o combate a situações de xenofobia, racismo, e/ou outros tipos de discriminação.

"Por fim, em 1919, os fundadores da OIT declaravam estar movidos «por sentimentos de justiça e de humanidade, assim como pelo desejo de assegurar uma paz mundial sustentável». Em 1944, afirmaram na Declaração de Filadélfia: «a luta contra a necessidade deve ser conduzida com uma energia inesgotável»." Em 2019, o Governo não quer só afirmar, quer mostrar, que 100 anos destes sentimentos não ficam no papel, mas que, efetivamente, melhoraram o mundo.

A Presidente

Muito obrigada, Senhora delegada. A mesa convida agora o Excelentíssimo Senhor delegado João Rovira representante do grupo dos Empregadores para se dirigir a plenária com seu discurso de posicionamento do seu grupo. Senhor delegado, o senhor tem 3 minutos.

$\overline{\text { JOÃO ROVIRA (em representação do grupo }}$ dos Empregadores)

Exma Senhora Presidente, Senhores delegados,
Começo por saudar todos os que participam nesta Conferência Internacional do Trabalho, em particular, saúdo o DiretorGeral Guy Rider e o importante relatório que aqui apresenta. Estou aqui em representação dos empregadores, particularmente em representação da confederação das das Pequenas e Médias Empresas portuguesas. Enquanto empregador o objetivo de qualquer empresa em resposta ao mercado é gerar uma situação de rentabilidade, produtividade e estabilidade que permita a criação de emprego duradouro. Para isso promovemos a inovação, o crescimento, a competitividade no setor empresarial, essenciais para a valorização do Futuro do Trabalho que aqui discutimos.

Os dados do IV Relatório da OIT sobre as PMEs, revelam que numa amostra de 18 países da OCDE as PMEs representam 63\% do emprego total. As PMEs representam também $95 \%$ de todas as empresas dos países da OCDE e são responsáveis por $60 \%$ a $70 \%$ do PIB. É de notar que um estudo econométrico recentemente feito na União Europeia refere que as taxas de crescimento são mais elevadas em países com mais PMEs. Através destes dados é naturalmente considerável que as Pequenas e Médias Empresas são um forte motor para o crescimento da nossa economia que tem de ser valorizado na criação futura de emprego.

Como é assinalado no documento em discussão, a mudança não afeta todas as empresas da mesma maneira. Hoje ser uma PME em Portugal tem um conjunto diverso de limitações que fazem com esse crescimento não seja tão acentuado como desejaríamos. Algumas das fortes limitações devido à crise financeira de 2008, particularmente visíveis numa economia pequena e aberta como a portuguesa, passam por um consumo interno deprimido e pelas sucessivas restrições de financiamento por parte de instituições financeiras, como é, aliás, assinalado no 
relatório, que nos impedem de competir de forma justa e de expandir a nossa força de trabalho. Outras limitações com considerável impacto futuro dizem respeito à concorrencial desleal de novas formas plataformas tecnológicas, promotoras da precariedade no trabalho, que não são afetadas pelo aparato burocrático e carga fiscal que recai sobre nós, verdadeiros criadores de emprego estável e de proximidade.

É necessário que exista por parte dos governos uma maior atenção às Pequenas e Médias Empresas, pois sem o seu desenvolvimento não existe nem crescimento, nem emprego. Sob a ameaça do desemprego, os jovens de hoje em dia estão cada vez mais a ganhar autonomia para desenvolverem os seus projetos através de "start-ups" ou a criação de microempresas. Os governos devem ser capazes de articular o aproveitamento das capacidades cognitivas e dos conhecimentos crescentes nas nossas sociedades com políticas económicas que discriminem positivamente o nosso tipo de empresa, forma crucial para não só criar emprego, como também enriquecer o futuro do trabalho através da inovação e do aumento de produtividade, fundamentais para a dinamização da procura e do crescimento. Somos e queremos ser o fator da mudança, queremos ser parte da solução para um futuro do trabalho digno.

Obrigado.

\footnotetext{
A Presidente

Muito obrigada, Senhor delegado. A mesa reconhece agora a Excelentíssimo Senhora Delegada Daniela Santos representante do grupo dos Trabalhadores para proferir o seu discurso. Senhor delegado, o senhor tem 3 minutos.
}

\section{DANIELA SANTOS (em representação do grupo dos Trabalhadores)}

Senhora Presidente,

Começamos por saudar todos os participantes desta Conferência Internacional do Trabalho e dar as boas-vindas e agradecer a presença do Senhor Diretor-Geral da Organização Internacional do Trabalho, felicitando-o pelo excelente relatório que está em discussão nesta Conferência.

Senhor Presidente, o aumento dos problemas na esfera laboral encontra-se espelhado nos números do desemprego que atinge cerca de 200 milhões de pessoas em todo o mundo, um número assustadoramente real. Mais ainda se considerarmos os 839 milhões de trabalhadores a ganhar menos de 2 dólares por dia, o que representa um terço da força de trabalho mundial.

Como representantes do Grupo dos Trabalhadores e também como jovens universitárias e mulheres que estão prestes a entrar no mundo do trabalho, as nossas preocupações centram-se sobretudo no desemprego jovem e na desigualdade de género. Tal como é referido no relatório do Diretor-Geral da OIT que se discute nesta conferência, tanto a taxa de desemprego dos jovens é superior à taxa de desemprego média, como os homens são mais facilmente contratados, tendo um nível salarial superior ao das mulheres.

No caso português, a par dos números do desemprego jovem, é preocupante o elevado nível de precariedade registado, com sérias implicações ao nível da fuga de cérebros, nos casos em que os jovens com formação universitária procuram alternativas à precaridade laboral além-fronteiras.

Tendo em conta esta realidade, em julho de 2012, na sua conferência internacional anual, a OIT criou uma Resolução de modo a combater a crise associada ao desemprego 
jovem, propondo aos governos, empregadores e trabalhadores que promovam políticas macroeconómicas e incentivos fiscais e que fortaleçam e adotem medidas específicas e sustentáveis como, por exemplo, programas de emprego público e garantias para jovens. No entanto, este é um processo longo, que pode demorar a ser posto em prática e a produzir resultados concretos.

Estes e outros problemas sociais que irão ser discutidos nesta Conferência deverão motivar a OIT para promoção dos direitos humanos do trabalho, no sentido de continuar a intervir ao serviço da justiça social, como tem feito ao longo de quase um século de existência. A justiça social comporta elementos como a promoção do pleno emprego, a redução da pobreza associada ao desemprego e aos trabalhadores pobres, a proteção social e, principalmente, a prática incontestável dos princípios e direitos fundamentais no trabalho que, no caso português, graças à crise económica que se tem vivido nos últimos anos, estão longe de ser efetivos.

Estamos convictas que desta Conferência irão sobressair elementos essenciais que contribuirão para a prossecução destes fins e, portanto, para um mundo do trabalho mais justo.

\footnotetext{
A Presidente

Muito obrigada, Senhora delegada. A mesa convida agora o Excelentíssimo Senhor delegado Jaime Almeida representante do grupo dos Governantes para se dirigir a plenária com seu discurso de posicionamento do seu grupo. Senhor delegado, o senhor tem 3 minutos.

JAIME ALMEIDA (em representação do grupo dos Governantes)
}

É com grande honra que saudamos a Presidente, o Sr. Diretor-Geral, bem como todos os participantes desta Conferência, e aceitamos o desafio, colocado através da realização da Conferência Internacional do Trabalho, com o intuito de discutir questões que preocupam todas as partes desta estrutura tripartida.

Sem descurar a importância de outras temáticas, sejam elas a desigualdade salarial entre géneros, a falta de condições de saúde no trabalho ou, até mesmo, a ainda existência do trabalho infantil, é de grande importância, considerando que esta conferência se executa no seio do ambiente académico, trazer para o debate a seguinte questão:

"Poderá ser a idade um fator criador de desigualdades no trabalho ou no acesso a ele?"

Este tipo de interrogação coloca-nos perante várias preocupações como sejam a sustentabilidade dos sistemas de Segurança Social, o elevado desemprego entre os jovens, a falta de apoios sociais para pensionistas e as barreiras no acesso ao trabalho por parte de dois grandes grupos etários, os jovens e os "grandes adultos".

Estes grupos etários possuem características distintas. Por um lado, os jovens estão no início da sua atividade laboral e esperam que o seu trabalho lhes proporcione uma carreira de sucesso, e por outro lado, a grande maioria dos "grandes adultos" devido a fatores de índole pessoal e familiar apresentam uma menor disponibilidade e mobilidade geográfica.

Em termos de coesão e justiça social, é necessário definir políticas de emprego sustentáveis que permitam a inclusão no mercado de trabalho dos grupos, acima referidos. Esta prioridade não só espelha princípios e compromissos internacionais já assumidos e adotados (dos quais destaco a Convenção n. ${ }^{\circ} 122$ relativa às políticas de 
emprego de 1964, ratificada por Portugal a 31. 07.1980), como se torna uma urgência num mundo do trabalho em constante mudança e turbulência.

O desafio atual para o governo, relativamente ao emprego, reside na relação cada vez mais frágil entre crescimento $\mathrm{e}$ criação de emprego de qualidade, sendo necessário colocar como prioridades nas agendas políticas o pleno emprego e o trabalho digno para todos desenvolvendo estratégias para alcançar este objetivo.

É de realçar que não somos pioneiros na reflexão relativa a este assunto e que todos os contributos, quer a nível nacional ou supra, devem ser tidos em consideração.

A nível nacional, uma política de emprego coerente, integrada, adequada aos recursos do país, que seja transversal às dimensões macro e microeconómicas e, essencialmente, que permita conciliar as necessidades do Grupo de Trabalhadores com as dos Empregadores por forma a assegurar o acesso a um trabalho digno para todos. Nesta medida, o debate deve basear-se em torno de duas questões fundamentais no mundo do trabalho atual:

"Que condições, atuais e futuras, podem esperar os jovens que iniciam a sua atividade laboral?"

"O trabalho precário beneficia as empresas e/ou os trabalhadores? Se sim, até que ponto?"

Tendo como base o princípio de igualdade e justiça social, compete ao Governo e aos parceiros sociais sob a base do diálogo social assegurar os interesses de todas as partes envolvidas, atendendo a fatores como a mobilidade, a flexibilidade e a prioridade regional de grupos etários distintos.

Convicto que para todos estes problemas atuais é possível encontrar uma solução, é de realçar a necessidade de tomar decisões com vista a uma maior dignidade e segurança no emprego destes dois grupos etários, sem detrimento da resolução de questões como a desigualdade de géneros, condições de trabalho, apoios sociais, entre muitas outras que se encontram dentro do mandato da OIT para um trabalho decente e produtivo, em condições de liberdade, equidade, segurança e dignidade.

GIOVANNI BEGOSSI (em representação do grupo dos Empregadores)

Obrigado, Excelentíssima Senhora Presidente. Em nome da delegação dos empregadores do setor industrial, gostaria de cumprimentá-la, bem como ao Excelentíssimo Senhor Diretor-Geral da Organização Internacional do Trabalho, Sr. Guy Ryder, através do qual estendo o cumprimento aos demais ouvintes e autoridades presentes, em especial aos ilustres Delegados e Delegadas.

Em 1929, o colapso da Bolsa de Valores de Nova York deu início à Grande Depressão. Esse período de recessão económica foi caracterizado por altas taxas de desemprego, quedas drásticas do produto interno bruto e da produção industrial de diversos países, dentre outras consequências drásticas tanto para trabalhadores quanto para empregadores.

Nesse mesmo ano, o poeta e dramaturgo alemão Bertold Brecht começava a escrever sua peça "A Santa Joana dos Matadouros". Seu objetivo era denunciar a desigualdade, a miséria e a injustiça decorrentes do sistema 
económico global. Para tanto, utilizou-se do exemplo da indústria da carne de Chicago do século XX. Jornadas de trabalho hercúleas, total desrespeito pelo direito de associação, salários irrisórios e condições de trabalho desumanas são apenas algumas das aflições da classe operária retratadas na peça.

Senhora Presidente, Senhoras e Senhores. Hoje, olhando para trás, podemos reconhecer que diversos avanços foram feitos nessas áreas, muitos dos quais protagonizados pela OIT. Cito, por exemplo, as convenções da OIT relativas: a) à duração do trabalho na indústria, de 1919; b) ao direito de organização e de negociação coletiva e à proteção do salário, ambas de 1949; e c) à segurança e saúde dos trabalhadores, de 1981.

Senhora Presidente, Senhoras e Senhores. Falar do futuro do trabalho implica falar de seu presente e passado, pois o presente nada mais é que o futuro do passado. $\mathrm{O}$ contexto não é mais o da indústria da carne de Chicago do Século XX, mas a desigualdade, a miséria e a injustiça apontados por Brecht persistem. Em Portugal, a taxa de desemprego atingiu $10,7 \%$ (são quase 551 mil pessoas sem emprego), 27,4\% dos jovens estão desempregados e 19,5\% da população está em risco de pobreza.

Senhora Presidente, Senhoras e Senhores. O futuro do trabalho perpassa por mais emprego, mais emprego jovem e empregos mais dignos. Porque só desse modo também os empregadores poderão ver prosperar as suas iniciativas de negócio. E tal como a direção da caminhada é mais importante que a velocidade da passada, reconhecer os erros e valorizar os acertos nesses quase 100 anos de OIT é um primeiro passo fundamental na longa jornada em direção a uma globalização livre de desigualdade, livre de miséria e livre de injustiça.

Muito obrigado.

\begin{abstract}
A Presidente
Muito obrigada, Senhor delegado. A mesa reconhece agora a Excelentíssima Senhora delegada Larissa Oliveira representante do grupo dos Trabalhadores para proferir o seu discurso. Senhora delegada, a senhora tem 3 minutos.
\end{abstract}

$\overline{\text { LARISSA OLIVEIRA (em representação do }}$ grupo dos Trabalhadores)

Senhora Presidente da Mesa desta Conferência Internacional do Trabalho Joana Ricarte, Excelentíssimo Senhor Diretor Geral da OIT Guy Ryder, senhores e senhoras delegados e delegadas desta Conferência, o que motivou eu e minha colega, a elaborar o presente discurso é o antagonismo que existe entre a utilização da tecnologia e a criação e manutenção de vagas de emprego a nível global, o que representa grande preocupação para o mundo do trabalho e seu futuro, não somente pela vida de cada cidadão trabalhador, mas pelo risco de afastar do mundo do trabalho a justiça social plena consagrada pela Declaração da OIT de 2008 (Sobre Justiça Social para uma Globalização Justa) e como bem elucidado no Relatório do Senhor Diretor Geral da OIT, sobre $O$ Futuro do Trabalho - Iniciativa do Centenário.

Como pode ler-se no capítulo 2 deste relatório, o facto de em cada ano ingressarem 40 milhões de pessoas torna expectável que, até 2030, se criem na economia mundial 600 milhões de novas vagas de emprego. Porém, se a tecnologia permanecer sendo utilizada como forma de substituição da mão de obra humana, então teremos um grave problema no futuro: nós, jovens, que estamos em processo de qualificação e formação profissional não teremos qualquer colocação profissional.

Dessa forma, é de extrema importância que todos os agentes estatais e privados envidem 
todos seus esforços no sentido de garantir a toda população economicamente ativa um emprego digno em condições justas, sendo que a tecnologia deve ser instrumento de inserção e integração, nunca instrumento de exclusão ou de substituição da mão de obra. Os Estados, os sindicatos, as grandes empresas multinacionais, devem trabalhar de forma incansável e articulada para conferir sentido de humanidade e dignidade plena à mão de obra, ou não fosse esta uma necessidade básica dos seres humanos.

Nesse mesmo sentido a nossa preocupação com o futuro do trabalho também reside no facto de que atualmente grandes empresas multinacionais relocalizam segmentos do seu processo produtivo, instalando-se em países subdesenvolvidos com o intuito de explorar a mão de obra trabalhadora: exigem produção em larga escala com jornadas de trabalho exaustivas e baixos salários e, assim, deixam de gerar empregos em seus países de origem, onde, na maioria dos casos, existe mão de obra qualificada para exercer as funções necessárias. Frequentemente, fazem também uso do trabalho escravo e infantil com vista a maximizar os lucros, rentabilizar o trabalho e reduzir os custos, indo totalmente contra os princípios da Declaração Universal dos Direitos Humanos.

Dessa forma, consideramos ser essencial, especialmente frente ao brilhante conteúdo do Relatório O Futuro do Trabalho - Iniciativa do Centenário e igualmente na sequência da Declaração de 2008 Sobre Justiça Social para uma Globalização Justa, que os Estados promovam políticas eficazes, como incentivos fiscais e tributários, que estimulem e regulem as grandes empresas multinacionais na geração de empregos dignos capazes de proporcionar a realização pessoal e profissional da população economicamente ativa em seus próprios países. Não obstante poder ser necessário recorrer a mão de obra internacional, anseia-se que tal processo decorra de forma plenamente digna, nos moldes definidos pela Organização Internacional do Trabalho.

Enquanto jovens estudantes e preocupadas com o futuro do trabalho e sua organização, consideramos essencial que sejam dadas oportunidades aos jovens de demonstrar o seu potencial, permitindo que se insiram no mercado de trabalho, uma vez que a taxa de desemprego dos jovens é muito superior à taxa de desemprego media da população e é, em muitos casos, duas vezes superior.

O que esperamos, para o futuro do trabalho e para a plena implantação da justiça social é que o emprego das tecnologias seja um fiel aliado dos novos trabalhadores que, com certeza, poderão aumentar sua produtividade e processo criativo e assim, conquistarem um trabalho digno com remuneração justa, que são decisivos para a sua realização pessoal.

Agradeço a todos os delegados e delegadas desta conferência pela vossa atenção.

\begin{tabular}{l}
\hline A Presidente \\
\hline Muito obrigada, Senhora delegada. A mesa \\
convida agora a Excelentíssima Senhora \\
delegada Sandra Graça representante do \\
grupo dos Governantes para se dirigir a \\
plenária com seu discurso de posicionamento \\
do seu grupo. Senhora delegada, a senhora \\
tem 3 minutos.
\end{tabular}

SANDRA GRAÇA (em representação do grupo dos Governantes)

Inicio a minha intervenção saudando, com muita honra a Exma. Sr. ${ }^{a}$ Presidente da Conferência, o Exmo. Sr. Diretor-Geral da OIT, Exmos. Srs. Delegados, muito bom dia a todos.

A agenda desta Conferência centra-se no trabalho e no futuro do trabalho. São muitos os questionamentos e de várias índoles: as 
dificuldades que os governos hoje enfrentam para garantir uma sã concorrência no mundo empresarial, promover o desenvolvimento económico e a criação de postos de trabalho e simultaneamente garantir condições de trabalho dignas. Estas são matérias de grande complexidade e acarretam sérios desafios.

Gostamos de enfrentar desafios e é com o propósito de os alcançar que estamos hoje aqui, sempre prontos para defendermos os valores em que acreditamos na construção de uma sociedade cada vez mais justa $e$ equilibrada.

É com esta intenção que julgamos de extrema importância trazer para este debate o trabalho clandestino, também chamado trabalho a negro, problemática abordada dentro dum conceito mais amplo pela OIT ao nível da economia informal. Os indicadores revelam um crescimento desta realidade que se traduz em níveis de precaridade e de pobreza alarmantes. Os trabalhadores clandestinos são sem dúvida os mais desprotegidos, porque estão despidos de qualquer ideia de direito e sujeitos às condições que lhes são impostas, na maioria das vezes em situações de desespero e necessidade absoluta. Os governos devem, por isso, considerar o grande número de trabalhadores e trabalhadoras, e de empresas, que não são reconhecidos nem protegidos por nenhuma moldura legal ou regulamentar, e que se caracterizam por uma grande vulnerabilidade e pobreza.

Neste domínio resta acrescentar a injusta concorrência com que as empresas cumpridoras se deparam face ao dumping social praticado sem escrúpulos pelas entidades que beneficiam e exploram estes trabalhadores.

Torna-se imperioso tomar medidas de combate a este flagelo que é comum a todos e que a todos preocupa. A OIT tem tido um trabalho louvável neste combate, de que é exemplo a convenção $n^{\circ} 81$ sobre a inspeção do trabalho de 1947, criada com o objetivo de um sistema de inspeção do trabalho que garanta a aplicação das disposições legais em vigor relativas às condições de trabalho e à proteção dos trabalhadores nos locais de trabalho, alertando as autoridades competentes para possíveis lacunas na lei. E é com esse desiderato que nos comprometemos a articular esforços e energias para garantir condições justas, salubres e condignas a todos os que trabalham, para que o trabalho, e no trabalho, o respeito pela pessoa humana e a pela sua dignidade sejam garantidos, bem como o desenvolvimento de uma economia sã, justa e igualitária.

\begin{tabular}{l}
\hline A Presidente \\
\hline Muito obrigada, Senhora delegada. A mesa \\
convida agora a Excelentíssima Senhora \\
delegada Daniela Rodrigues representante do \\
grupo dos Empregadores para se dirigir a \\
plenária com seu discurso de posicionamento \\
do seu grupo. Senhora delegada, a senhora \\
tem 3 minutos.
\end{tabular}
tem 3 minutos.

\begin{tabular}{l}
\hline DANIELA RODRIGUES SANTOS (em \\
representação do grupo dos Empregadores) \\
\hline
\end{tabular}

Ilustre secretário-geral da OIT, delegados, experts e todos os presentes,

No contexto do relatório em discussão sobre o "Futuro do Trabalho", começo pelas más notícias: a OCDE considerou este ano que Portugal é o $4^{\circ}$ pior país para trabalhar e o $9^{\circ}$ país com salários mais baixos da União Europeia; por outro lado, muitos estudos avançam que desde a crise financeira de 2008 até agora foram destruídos 1 em cada 7 empregos e já não se pode considerar que a causa é a falta de qualificação dos portugueses.

No entanto, é mais urgente e pertinente falar dos problemas estruturais que dos 
problemas de conjuntura económica, por isso vou abordar um deles.

Os empregadores encontram-se preocupados com o futuro da lei do trabalho. São cada vez mais intensas as pressões exercidas pelos sindicatos para a abolição dos contratos de duração flexível. Embora estes possam não ser ideais para os trabalhadores, permitem às empresas adaptarem-se a um ambiente de mudança.

A crescente internacionalização da produção, acompanhada de alterações rápidas e profundas provocadas pelo progresso tecnológico e a procura da competitividade, faz com que a flexibilização da contratação seja uma oportunidade de crescimento, adaptação e mudança para as empresas.

A tecnologia tem eliminado muitos postos de trabalho, no entanto também é responsável pelo aumento da eficiência das empresas e pela amplificação da gama de produtos à disposição do consumidor final, aumentando o bem-estar geral. Para além disso, só o trabalho mecanizado é passível de ser substituído por máquinas, pelo que aos trabalhadores são deixadas as tarefas de natureza intelectual que valorizam o capital humano.

Uma questão pertinente dos dias de hoje é “o que é que o futuro nos reserva?", se as plataformas online vão substituir o atendimento direto aos clientes (ou diminuir o $\mathrm{n}^{\mathrm{o}}$ de postos de trabalho), como aconteceu com bancos online, ou portais da Segurança Social e Finanças. Qual a necessidade de analistas (de risco, por exemplo), estatísticos ou contabilistas quando softwares de tratamento de informação e de análise de cenários se banalizarem?

Tanto a globalização como a forma como a evolução tecnológica tem afetado o emprego são preocupações expressas no documento o "Futuro do Trabalho", onde é afirmado que "o acesso ao trabalho é uma condição prévia à realização pessoal e à inclusão social". Por outro lado, só há criação de emprego se as empresas forem bem-sucedidas.

Ora, não é com políticas fiscais apertadas elaboradas pelo Governo ou com a pressão exercida constantemente pelos sindicatos, muitas vezes traduzidas em greve dos trabalhadores, que vamos alavancar as empresas, a economia ou o país. Há uma necessidade maior do que nunca de criar consensos se queremos mitigar os problemas que hoje nos afetam.

Nesse sentido, propomos que o Governo equacione a possibilidade de cofinanciamento da formação dos trabalhadores, medida que aumentará não só a competitividade das nossas empresas, mas também as competências dos nossos colaboradores e a sua valorização.

Muito obrigada.

\section{A Presidente}

Muito obrigada, Senhora delegada. A mesa reconhece agora o Excelentíssimo Senhor Delegado Luiz Faria representante do grupo dos Trabalhadores para proferir o seu discurso. Senhor delegado, o senhor tem 3 minutos.

LUIZ FARIA (em representação do grupo dos Trabalhadores)

Muito obrigado. Senhora Presidente da Conferência; Secretários da Conferência; Vossas Excelências; Senhoras e Senhores, delegadas e delegados da Conferência, Excelentíssimo Diretor Geral da Organização Internacional do Trabalho, Guy Ryder.

Gostaria de começar por salientar a importância do Relatório "O Futuro do Trabalho" e da proposta de estratégia de atuação deste que culminará numa promissora Conferência no centenário da OIT. Nele, são 
retratados alguns problemas fundamentais que envolvem o futuro do trabalho.

Dentre os temas retratados - e como representante do grupo dos trabalhadores ressaltarei um tema que considero de importantíssima relevância: a justiça social. Atualmente nos defrontamos com crescentes desigualdades, resultantes da globalização económica, sendo os direitos dos trabalhadores instrumentalizados. Tendo em consideração as rápidas mudanças no mundo do trabalho, para os trabalhadores é fundamental uma preocupação com o futuro da justiça social.

Primeiramente, torna-se necessário exortar a todos a fazer uma reflexão, para melhor compreensão do tema. Nas palavras do filósofo e escritor Mario Sergio Cortella “(...) quando estamos a falar de Trabalho $e$ Emprego temos que os diferenciar. Emprego é fonte de renda e Trabalho é fonte de vida, ou seja, muitas pessoas encontram no emprego o trabalho querem ter, isto é, a obra que querem produzir".

Data vênia, na leitura do relatório, vemos uma certa utopia, orientações subjetivas, e não os termos práticos e objetivos da sua aplicação, pois hoje nota-se somente a vontade de Governos para mostrar estatísticas, preocupando-se com uma plena empregabilidade, sem ao menos se preocuparem como é que os direitos dos trabalhadores estão sendo efetivados. Mesmo assim, consideramos o relatório de extrema importância até mesmo para orientação dos trabalhos e campos de atuação, na medida em que a Justiça social se funda num princípio básico que é a igualdade que está prevista em todas as Constituições e também está associada à não descriminação em matéria de emprego e de profissão, também consagrada nos Princípios e Direitos Fundamentais no Trabalho, de 1998.

Excelentíssimo Diretor Geral,
Temos um elevado acervo constituído por 7500 ratificações de convenções. Temos a Declaração relativa aos Princípios e Direitos Fundamentais no Trabalho, de 1998. E, agora, o relatório "O Futuro do Trabalho" para a $104^{a}$ Sessão da Conferência Internacional do Trabalho, de 2015.

Justificam-se, porém, duas observações:

A primeira diz respeito a uma questão já bastante discutida, mas que deveria ser ainda mais, e que é certamente a questão do século quanto à justiça social. Quando falamos de emprego como fonte de rendimento, como pode haver tamanha desigualdade salarial no atual estágio do mundo capitalista?

A segunda remete para o Trabalho como fonte de vida, pois estamos hoje num estágio em que as pessoas despendem o esforço e energia, física ou psíquica, em atividades em que o trabalho, neste sentido, assume um caráter penoso. Para Marx, isto só resolveria com a redução da jornada de trabalho. Data vênia, a realidade que vemos hodiernamente não é, de todo, esta, quando falamos da jornada de trabalho, o que suscita uma mudança iminente.

Para terminar e fazendo uma metáfora como a expressão da escritora francesa Sidonie Colette "Le tout est de changer", pergunta-se como a OIT atuará para que estes temas sejam pautas de discussões efetivas e construtoras de soluções na próxima Conferência e não sendo mais uma vez instrumentalizada por interesses?

\section{Comentários pelo Diretor-Geral da OIT}

\section{A Presidente}

Muito obrigada a todos os delegados e todas as delegadas por seus excelentes discursos que serão comentados pelo Excelentíssimo Senhor Diretor-Geral da Organização Internacional do Trabalho, a quem concedo agora a palavra. 
(fala o Diretor-Geral da OIT)

Encerramento da Sessão

A Presidente

Muito obrigada Senhor Diretor-Geral. A Presidência tem a honra de encerrar os trabalhos desta manhã propondo o adiamento desta sessão plenária. Vamos iniciar o processo de votação, lembrando que esta é uma questão procedimental e que, portanto, não há lugar a abstenções.

(não havendo objeções, a sessão plenária foi adiada até dia 30 de novembro às 14h30)

\section{Dia 1}

\section{Sessão Plenária dos Comités}

Quinta-feira, 20 de outubro de 2016, 14h30

A Sessão Plenária de Comités iniciou-se com a exposição de questões procedimentais que antecederam as Sessões de Trabalho dos Comités. Daqui resultou a aprovação das seguintes temáticas para trabalho em Comité:

1- A macro regulação económica do emprego. Do pleno emprego à plena empregabilidade?

2- Novas Tecnologias: fim do trabalho ou fim do emprego?

3- Trabalho desigual? Novas formas de desigualdade e a organização do trabalho.

4- O futuro das relações de trabalho: direito ao trabalho e o direito do trabalho.
Posteriormente, a Presidente da CIT apresentou, pelos poderes que lhe foram confiados, os membros do secretariado responsáveis por dar início aos trabalhos em Comité.

- Como Secretária do Comité 1, Sandra Graça;

- Como Secretária do Comité 2, Vanda Amaro Dias;

- Como Secretária do Comité 3, Teresa Maneca;

- Como Secretária do Comité 4, Andreia Santos.

(não havendo objeções a Sessão Plenária dos Comités deu-se por encerrada)

\section{Dia 1}

\section{Primeira Sessão de Trabalho dos Comités}

Quinta-feira, 20 de outubro de 2016, 15:15

\section{Comité 1 -A macro regulação económica do} emprego. Do pleno emprego à plena empregabilidade?

$\frac{\text { Abertura da Sessão }}{\text { SANDRA GRAÇA (Secretária do Comité 1) }}$
A secretária do Comité, Sandra Graça, deu
as boas vindas a todos/as os/as delegados/as e


procedeu à apresentação da agenda de trabalhos. Em seguida, explicitou o regulamento interno e o modus operandi específico do Comité.

Procedeu-se à eleição dos seguintes cargos:

- Presidente da Mesa, entre os/as delegados/as representantes do Governo. Por unanimidade foi eleita Ana Carolina Novais.

- Vice-presidente em representação dos trabalhadores. Por unanimidade foi eleita Wu Dzi Wen.

- Vice-presidente em representação dos empregadores. Por unanimidade foi eleita Jordana Birck.

A presidente da mesa, Ana Carolina Novais, assumiu os trabalhos do Comité pedindo aos peritos do Secretariado para fazerem uma apresentação sobre os trabalhos do Comité, com o intuito de melhor enquadrar o debate geral.

(seguiu-se a apresentação do tema pelo perito do Secretariado da ConferênciaNuno Teles)

\section{Debate Geral}

$\mathrm{O}$ debate geral iniciou-se com a intervenção de José Oliveira, do grupo dos Governantes, que destacou os dois grandes problemas que, na sua opinião, marcam o mercado de trabalho e os desafios associados ao crescimento da economia, desde 2008. Em primeiro lugar, o problema do desemprego que atingiu valores record durante a administração de José Sócrates. A solução apresentada pelo Governo em funções passou por aumentar os gastos públicos (autoestradas, hospitais, etc.), o que se repercutiu numa redução dos níveis de desemprego, mas que por outro lado aumentou a dívida pública. $\mathrm{O}$ equilíbrio das contas internas deu-se, portanto, às custas do desequilíbrio das contas externas. Por outro lado, com a intervenção da troika em Portugal esta situação inverteu-se - assistiu-se a um desequilíbrio das contas internas para salvaguardar as contas externas. Neste senário a grande questão que se coloca é a de como equilibrar de forma harmoniosa contas internas e externas, uma vez que isso será crucial para criar uma economia favorável à criação e manutenção de emprego. Estas questões foram respondidas por Diogo Videira, também representante dos Governantes, que salientou que essa é uma situação que não sido possível articular. Para além disso, destacou as dificuldades inerentes à exportação e ao crescimento económico sem prejuízo para os trabalhadores.

Seguiu-se a intervenção de Carmo Gouveia, do grupo dos Empregadores, focando a questão das exportações e salientando que Portugal tem investido e exportado turismo, mas que permanece por explorar uma dimensão económica que beneficie os portugueses. Refere também que teve 3 PMEs empenhadas em dar condições aos trabalhadores, mas que isso foi impossível de realizar devido à falta de consumo. Salienta ainda que o setor do turismo não está a crescer de forma sustentável no longo prazo, uma vez que assenta numa força laboral não qualificada. Para além disso, o crescimento deste setor tem provocado inflação nos principais centros turísticos, bem como uma degradação da qualidade de vida nestas zonas. Neste sentido, afirma que o turismo não está a cumprir o objetivo de financiar o país, nem de preservar o património nacional. Como alternativa, sugere uma maior aposta em indústrias qualificadas, ao invés do investimento em criação de empregos precários e de baixa qualificação que apenas beneficiam uma lógica de lucro imediato e 
descuram questão de sustentabilidade, e crescimento sustentado no curto, médio e longo prazo.

A intervenção do delegado João Reis, do grupo dos Governantes, centrou-se na questão de como aliar o crescimento económico ao bem-estar social. Neste contexto, destacou a necessidade de apostar na economia verde, um ponto capaz de reunir sinergias tanto de empregadores como de trabalhadores. Realça o cariz pouco desenvolvido deste tipo de economia, quando comprado com economias mais tradicionais. No entanto, salienta que, num contexto de crescente globalização, Portugal tem que apostar nos seus recursos naturais como forma de reforçar a sua economia. O caminho das energias renováveis deve, portanto, ser a grande aposta de Portugal. Isso reforçaria a indústria portuguesa, uma vez que o país tem os recursos e mão de obra qualificada nesta área. Uma economia verde exige pessoas qualificadas e bem remuneradas, o que contribui para o bem-estar social e psicossocial dos trabalhadores. Esta é uma tendência que mais tarde ou mais cedo vai assumir uma dimensão global e Portugal deveria apostar em ser pioneiro neste contexto.

Luís Fernando Faria, do grupo dos Trabalhadores alertou para o fato dos códigos de trabalho serem meramente ornamentais, uma vez que existem inúmeros casos de violação aos mesmos. Para além disso, referiu a urgência de se encontrarem soluções práticas para a atual conjuntura económica. Será essa solução a via liberal?, indagou. No seu entendimento, Portugal não tem oferecido nada aos trabalhadores. Os recibos verdes não oferecem garantias e não são aceitáveis. A criação de períodos de formação não é suficiente para dar segurança aos trabalhadores. A emigração também não pode ser vista como solução para o desemprego em
Portugal. Por fim, os sindicatos não têm conseguido representar os trabalhadores, nem defender os seus interesses e também nesta área urge um debate profundo na sociedade portuguesa.

O delegado Francisco, do grupo dos Governantes, esclarece que a economia aberta, baseada no contexto português dos anos 1980/90, levou a que as empresas se deslocalizassem para mercados mais competitivos, o que acabou por se traduzir no aumento do desemprego. Por seu turno, a crise internacional dos últimos anos levou ao endividamento dos Estados e à sua incapacidade de pagar as suas dívidas externas. Nesse sentido, uma questão que deve ser alvo de debate é como controlar o défice e como diminuir o desemprego sem descontrolar as contas públicas.

Navvab Aly, do grupo dos Trabalhadores, sugere orientar a discussão para um modelo de crescimento equilibrado e que, apesar de tudo, o capitalismo tem sido o modelo económico mais bem-sucedido na história contemporânea. Contudo, como qualquer sistema em evolução, precisa de reformas para acompanhar os desafios crescentes de um mundo globalizado. Falar de globalização, como um processo igual, é também algo que considera incorreto, uma vez que nem todos os países estão a responder da mesma forma a este processo (e.g. Portugal, Grécia, países africanos, etc.). Qualquer reforma tem que ter em conta os contextos específicos de cada país - globalização não pode ser uniformização. Apela ao Governo para que adote medidas para criar emprego e para valorizar os jovens, sendo que os refugiados capazes de se adaptar ao mercado de trabalho, de se qualificarem e de contribuir para o crescimento económico - merecem particular cuidado nesta discussão.

José Vasco, do grupo dos Empregadores, pede um maior papel do Estado na economia 
e uma maior compreensão do estado do Estado. Portugal é um dos países mais endividados do mundo, o que inclui tanto o setor público, como o setor privado. Portugal deve ser capaz de atrair capital estrangeiro e aumentar as suas exportações para gerar riqueza. Contudo, esta riqueza não pode ser gerada por decreto. Ela depende de investimento, aumento de produtividade e da garantia da propriedade privada. Nesse sentido, propõe redução nas despesas do Estado e uma diminuição da carga fiscal. Para diminuir a despesa pública urge: 1) reduzir o número de funcionários públicos; 2) reduzir o salário dos funcionários públicos; 3) reduzir as transferências sociais. Este tipo de reformas constitui o caminho para tirar os países da pobreza. Esta intervenção suscitou um pedido de resposta - "Como é que a despedir funcionários públicos aumentamos o emprego" - ao que o delegado esclareceu que existe um excesso de funcionários públicos em Portugal.

Diogo Videira, do grupo dos Governantes, explica que a estagnação secular se deve à desregulação dos mercados financeiros e à falta de investimento. Atualmente, os mercados de derivados são apenas mercados de poupança. Se acabarmos com esta lógica o dinheiro aplicado nestes mercados será reinvestido e acabará com a estagnação económica global. Para que isto seja possível é necessário criar uma regulação global da economia através de instituições e de um Banco Global.

João Bento, em representação dos trabalhadores, alerta que as exportações são importantes, mas que não nos devemos tornar excessivamente dependentes delas, uma vez que isto aumenta a vulnerabilidade a choques externos. Frisa ainda que o consumo interno está a ser desvalorizado.

Francisco Gonçalves, do grupo dos Governantes, menciona que os juros da dívida pública constituem um grande encargo para o Estado. Deve haver uma maior aposta nas PMEs, e uma maior capacidade de atrair investimento externo. A flexibilização dos contratos de trabalho, nomeadamente o recurso a recibos verdes, poderia ajudar as empresas a serem mais flexíveis e a conseguirem competir no mercado internacional. Neste contexto, o Estado deve regular estas medidas que ajudariam na criação de emprego, mas não intervir com mais despesa pública.

Lucas Figueiredo, do grupo dos Governantes, sugere uma diminuição do IRC (imposto sobre empresas), pois isso é crucial para aumentar a capacidade de Portugal atrair investimento externo.

Mariana Pinheiro, do grupo dos Trabalhadores, reforça a ideia que Portugal deveria investir nos seus jovens.

Glauber Nunes, do grupo dos Empregadores, esclarece que na economia real quem investe quer retorno e que o Governo não gera ordem na economia; gera caos. Devemos promover uma menor intervenção do Governo, pois este prejudica os empregadores que, por seu turno, não contratam trabalhadores. $\mathrm{O}$ mercado autorregula-se e, logo, não precisa de governo.

Francisco Amaral, do grupo dos Governantes salienta que foram feitas várias propostas, mas que estas não são exequíveis. Os empregadores sugeriram o despedimento dos funcionários, o que afeta necessariamente o consumo interno. Os representantes do Governo propõem acabar com o financiamento da economia sem mencionarem alternativas concretas. Devemos olhar para a realidade e debater para chegar a propostas concretas, exequíveis e benéficas para todas as partes envolvidas.

O debate terminou com a intervenção de Carmo Gouveia, do grupo dos Empregadores. 
A delegada salientou a necessidade de se criaram condições para as empresas gerarem riqueza e gerar mais postos de trabalho. É necessário criar uma nova cultura e repensar os mecanismos de criação de emprego. Os empregadores precisam de regulação, estabilidade e ajuda.

Após as intervenções dos delegados seguiram-se intervenções pela Presidente e Vice-Presidentes do Comité acerca da importância dos trabalhos da Primeira Sessão em Comité.

Finalmente foi aprovada uma moção de encerramento, concluindo-se os trabalhos da Sessão de 20 de outubro.

\section{Comité 2 - Novas Tecnologias: fim do trabalho ou fim do emprego?}

\section{Abertura da Sessão}

VANDA AMARO DIAS (Secretária do Comité 2)

Boa tarde senhores delegados e senhoras delegadas,

$\mathrm{Na}$ minha qualidade como Secretária do Comité 2: Novas Tecnologias: fim do trabalho ou fim do emprego? é uma honra e um privilégio declarar aberta a primeira sessão de trabalho deste comité. Começo por mencionar brevemente as atribuições das autoridades do comité e as regras de funcionamento do mesmo.

\section{(segue-se uma exposição sobre questões procedimentais)}

Pelos poderes que me foram confiados passo a apresentar os membros da mesa propostos pelos respetivos grupos. Como Presidente, em representação do grupo dos Governantes, Rafaela Henz Dias. Rafaela Henz Dias é aluna do $2^{\circ}$ ano da Licenciatura em Economia na Faculdade de Economia da Universidade de Coimbra. É igualmente membro do Pelouro da Cultura no Núcleo de Estudantes de Economia e aluna de guia do Programa GPS das Relações Internacionais da Universidade de Coimbra.

Como Vice-Presidente indicado pelo grupo dos Trabalhadores, Tony Santos. Tony Santos é aluno do $4^{\circ}$ ano de Gestão da Universidade Federal de Alagoas (UFAL-Brasil). É aluno de intercâmbio pelo programa Santander de mobilidade luso-brasileira, através do convénio entre a UFAL e a Universidade de Coimbra. Foi membro do grupo Sociedade, Natureza e Desenvolvimento no Agreste Alagoano e aluno de iniciação científica vinculado ao Projeto Agreste entre 2013/2014. Foi coautor do livro Versões e Ponderações, através da Parceria entre a UFMS e a UFAL, bem como monitor das seguintes disciplinas: Economia, Introdução à Administração e Seminário Integrador II.

Como Vice-Presidente indicada pelo grupo dos Empregadores, Daniela Filipa Santos. Daniela Filipa Santos é aluna do $3^{\circ}$ ano de Gestão na Universidade de Coimbra; Team Member da AIESEC Coimbra NEFE; e colaboradora no projeto GPS. Participou como colaboradora do pelouro de relações externas do núcleo de estudantes de gestão e do pelouro de saídas profissionais da AAC.

Senhores delegados, senhoras delegadas, existem objeções à composição da mesa?

\section{(não se registaram objeções)}

Não havendo objeções, o secretariado confere plenos poderes aos membros da mesa para assumirem as respetivas funções e conduzirem os trabalhos deste Comité. Neste sentido, assume a condução dos trabalhos a Excelentíssima Presidente Rafaela Henz Dias.

Senhora Presidente a palavra é sua. 


\section{Discursos da mesa}

A Presidente do Comité 2, Rafaela Henz Dias, prosseguiu com a abertura dos trabalhos enfatizando a importância dos mesmos e a pertinência de discutir questões relacionadas com "As novas tecnologias: fim do trabalho ou fim do emprego?". Seguiu-se a eleição do Comité de Redação do Comité da qual resultou a seguinte constituição: David Luís Castro, do grupo dos Governantes; Lauren Victoria Bento, do grupo dos Empregadores; e Rita Brás, do grupo dos Trabalhadores.

A Presidente pediu aos peritos do Secretariado para fazerem uma apresentação sobre os trabalhos do Comité, com o intuito de melhor enquadrar o debate geral.

(seguiu-se a apresentação do tema pelos peritos do Secretariado da Conferência-

João Maia e Beatriz Caitana Silva)

A Vice-Presidente, Daniela Santos, interveio para introduzir os trabalhos do Comité, apelando aos delegados para terem em conta questões relacionadas com a promoção de um trabalho melhor e mais digno. Neste sentido, a Vice-Presidente enfatizou que flexibilidade não é, nem deve ser sinónimo de exploração e que cabe aos Governos procurar consensos e promover soluções para alcançar um futuro do trabalho melhor para todos.

O Vice-Presidente, Tony Santos, prosseguiu agradecendo a todos os delegados a sua participação nos trabalhos do Comité e realçando a pertinência do tema do mesmo.

Findos os discursos da mesa, a Presidente deu início ao debate geral, com intervenções pelos delegados dos Governantes, Empregadores e Trabalhadores.

\section{Debate Geral}

Tendo como ponto de partida a sugestão de debate deixada pelo magnífico Reitor da Universidade de Coimbra, em relação à possibilidade de taxar a utilização de máquinas e tecnologias que substituíssem diretamente postos de trabalho, o grupo do Governo demonstrou-se firmemente contra, discordando aliás que a tecnologia tivesse um carácter necessariamente disruptor na empregabilidade. Foi acrescentado que negar a tecnologia corresponderia a negar o conhecimento e que a tecnologia poderia dar um contributo para a existência de mais emprego qualificado, mais justo, realçando a importância da justiça social e a sua compatibilidade com o crescimento económico.

Aliás, a tecnologia é importante também para o empreendedorismo, que cresceu muito em quantidade e qualidade devido ao surgimento de novas tecnologias e novos usos das tecnologias já existentes. Da mesma forma, o teletrabalho, que está ligado necessariamente à tecnologia, é um importante fator de independência para quem escolhe ficar em casa a gozar de licença parental prolongada ou quem escolhe dedicarse em exclusivo ao trabalho doméstico. A maternidade e a necessidade de acompanhamento familiar são situações que, em algumas culturas, coagem a mulher a fazer uma opção entre família e um futuro profissional. Nestes casos, o teletrabalho é uma solução que empodera verdadeiramente quem se encontra em situações semelhantes e lhes permite apostar numa carreira profissional sem abdicar da vertente familiar.

A tecnologia é igualmente responsável pelo aumento da qualidade de vida e saúde ao permitir uma maior aposta na investigação. Da mesma forma, possibilita melhorias qualitativas e quantitativas em diversos sectores com impactos reais na vida civil e laboral dos cidadãos. 
Ao invés de adotar medidas que possam limitar o progresso, o governo encoraja a posição contrária, defendendo que se incentive o investimento através de regalias e bolsas de forma a "acompanhar a evolução dos tempos" por forma a evitar competitivas em relação a outras economias no mercado global.

Para além dos impactos positivos que estes incentivos à tecnologia teriam na economia, seriam também fator decisivo para reduzir a chamada "fuga de cérebros", de pessoas formadas e muitas vezes especialistas que emigram em busca de melhores condições de trabalho e de vida. Em suma, o incentivo à criação e evolução tecnológica aproximaria os Governos da sua dupla missão de incentivar o progresso e assegurar a justiça social.

Os delegados do grupo dos Governantes, realçaram ainda que os Governos não devem ser excessivamente intervencionistas, mas devem sempre agir no sentido de garantir o equilíbrio, a justiça e a livre concorrência. Por esse mesmo motivo não visam tomar medidas onerosas para os empregadores, nomeadamente a criação de novos impostos que dissuadam a aposta no investimento, a manutenção de postos de trabalhos e a criação de novas oportunidades de emprego.

Acrescentou-se o receio de que caso fosse aplicada ou recomendada taxação adicional aos empregadores, esta seria fator de instabilidade, gerando desconfiança entre os investidores e contribuindo para a redução do investimento. Isto porque o crescimento de uma economia encontra-se muitas vezes dependente de investimento externo e privado, que iria certamente diminuir face a uma situação de instabilidade fiscal, agravando o caso de alguns países cujos mercados já se encontrem numa situação débil.

Por último, introduziu-se a questão do género, referindo-se o facto de em alguns países já terem sido tomadas medidas de sucesso na promoção da igualdade de género no mercado de trabalho, como é o caso das quotas na administração pública e privada. Outras quotas de presença laboral mínima de um determinado género já foram também implementadas e podem ser uma ferramenta útil em algumas realidades nacionais.

A implementação de medidas de promoção da igualdade de género contribuirá para reduzir - e desejavelmente extinguir - o défice das mulheres no mercado trabalho, quer em presença quer em remuneração. Isto será tanto mais verdade quanto maior for a articulação com outras medidas, como a aproximação da regulação dos contratos de trabalho tradicionais e alternativos à verdadeira capacidade/realidade produtiva dos países, evitando a fuga da procura/oferta de trabalho para formas de trabalho informal precárias. Feita esta aproximação, uma efetiva fiscalização e legislação complementar no sentido de punir más práticas laborais decorrentes das alterações referidas, serão o último passo para garantir o cumprimento das regulamentações.

Os delegados do grupo dos Empregadores enfatizaram o fato da tecnologia ser uma realidade incontornável dos nossos tempos e uma mais-valia para os Governos, Empregadores e Trabalhadores se adaptarem às exigências de um mundo globalizado e em permanente evolução. Reconhecem que a tecnologia tem colocado muitos desafios ao emprego, com particular impacto no setor primário - aquele em que se verifica uma maior taxa de mecanização para garantir uma maior e mais eficaz produtividade. Por isso mesmo, urge uma aposta na qualificação crescente e permanente da mão-de-obra.

No entanto, os delegados do grupo dos Empregadores realçam que a tecnologia teve a mais-valia de introduzir mudanças significativas nos vários mercados de trabalho 
que levaram ao seu progresso. Se os nossos antepassados foram capazes de se adaptar às mudanças decorrentes das várias revoluções industriais, também a nossa sociedade será capaz de o fazer, procurando sempre maximizar os benefícios sociais, económicos e culturais num mundo onde a tecnologia ocupa um lugar cada vez mais proeminente. Neste processo é necessário garantir que a economia e a produtividade cresçam apoiadas pelo uso e potencialização das novas tecnologias. Para além disso, é preciso ajustar as taxas que recaem sobre empresas e trabalhadores, sobretudo quando esta taxação leva muitos empresários a apostar na mecanização como forma de escapar aos custos decorrentes da criação de emprego. Com o intuito de tornar as novas gerações mais empregáveis, realça-se ainda a importância de haver um processo de adaptação do sistema educativo que permita aos alunos um maior conhecimento $\mathrm{e}$ experiência para trabalhar com as novas tecnologias.

Não obstante as oportunidades geradas pelas novas tecnologias, os delegados do grupo dos Empregadores salientaram que os mercados de trabalho estão cada vez mais mecanizados, verificando-se um défice do elemento criativo, inerente e exclusivo do ser humano. Uma forma de valorizar o trabalho humano é apostar na criação de postos de trabalho criativos, mas também promover o fim do subemprego, uma vez que este, para além de não gerar lucro cria uma situação de precariedade para os trabalhadores, com elevados custos económicos e sociais. Uma grande aposta nesta área deve ser também a transformação do trabalho informal, por forma a garantir mais direitos e garantias para os trabalhadores, bem como a criação de empresas que ajudem este processo de transformação e o incentivo ao empreendedorismo e à criação de pequenas empresas - formação do próprio emprego. Para que tal suceda, é essencial diminuir a burocracia inerente à criação de novas empresas e postos de trabalho, bem como a criação de leis que regulem a produção de bens numa lógica de cooperação com os trabalhadores.

Sobre a questão do fim do trabalho, os delegados do grupo dos Empregadores defendem que enquanto o homem existir, haverá sempre trabalho. O que está em causa é uma transformação daquela que é o emprego tradicional - o "emprego para a vida" -, urgindo uma reorientação das relações de trabalho para facilitar uma melhor e mais suave adaptação à nova realidade introduzida pelas novas tecnologias. Nesta nova realidade, as tecnologias são essenciais e não devem ser encaradas como um obstáculo. Pelo contrário, elas permitem um leque de novas oportunidades. Contudo, estas oportunidades só podem ser aproveitadas se houver um investimento nos trabalhadores para que eles se possam qualificar devidamente com vista a beneficiar das mesmas. Simultaneamente, e para promover uma melhor adaptação à nova realidade social e laboral do século XXI os delegados do grupo dos Empregadores defendem a criação de incentivos para a manutenção de empresas, uma maior aposta na justiça social, maior facilidade no acesso ao crédito por parte de pequenas e médias empresas, uma real partilha de responsabilidades entre os vários parceiros sociais e a criação de mais linhas de crédito por parte do Governo.

O grupo dos Trabalhadores salientou que as novas tecnologias trazem muitas vantagens e que esse é um ponto incontestável. No entanto, chama a atenção para a necessidade de haver uma preocupação com aquela que tem sido uma linha ténue entre a precarização do trabalho e a inovação tecnológica. Como tal, urge que as empresas deixem de se 
preocupar exclusivamente com a produção em larga escala e se comecem a preocupar também com o estímulo da criatividade dos seus trabalhadores. A tecnologia é importante, mas não deve nunca ser usada como meio de cristalizar condições precárias para os trabalhadores. Os delegados do grupo dos Trabalhadores alertaram para a tensão flexibilização vs precarização e para a necessidade de não confundir estes dois conceitos. É fundamental flexibilizar as relações de trabalho e incluir na agenda pública questões de educação no sentido de melhor preparar os futuros trabalhadores. Com isto enfatizam que não defendem uma postura de protecionismo total dos trabalhadores, mas antes uma postura de justiça social que proteja os direitos já existentes face às novas condições dos mercados de trabalho.

O grande problema, defendem, não é o aparecimento de novas tecnologias. $\mathrm{O}$ grande problema é o trabalho digno não andar a par e passo com o avanço tecnológico; é não preservar os direitos sociais, culturais e a requalificação dos trabalhadores. A dimensão da educação é incontornável, pois é nela que se prepara o trabalhador para os desafios que vai encontrar. Não se trata de abolir as máquinas, nem a mecanização, mas de centrar o foco em medidas que preparem os atuais e futuros trabalhares para as exigências e desafios crescentes dos mercados de trabalho.

Entre estes desafios está incontornavelmente a questão da precarização. É verdade que as novas tecnologias trazem novos espaços (online) com diferentes espaços de atuação e luta. Porém, estes novos espaços são também espaços de desigualdade. Se, por um lado, as novas tecnologias podem promover novas formas de trabalho que se podem associar a uma individualização do trabalho mais positiva que conduz à capacitação, à autonomia e à flexibilização de horários; por outro lado, estas tecnologias fizeram emergir novas formas de trabalho sem vínculos contratuais ou garantias sociais. Uma questão importante é, portanto, saber como se transforma este tipo de trabalho em emprego digno. Por emprego entenda-se o trabalho ao qual se associou um conjunto de direitos sociais que têm sido negligenciados nos últimos anos, com graves consequências para os trabalhadores e o tecido social no seu todo.

Por tudo isto, concluem, que o problema não reside nas novas tecnologias, mas na forma como elas têm sido utilizadas. Tradicionalmente, o trabalho estava orientado para o suprimento de necessidades. Com uma mudança sistémica global e o surgimento das novas tecnologias esta lógica alterou-se e o trabalho é agora marcado por uma lógica de lucro, muitas vezes desprovido de limites de exploração, onde o trabalho e os recursos se tornam em meras mercadorias. É justamente esta lógica que é preciso combater e transformar por um trabalho melhor e um mundo mais justo.

Após as intervenções dos delegados seguiram-se intervenções pela Presidente e Vice-Presidentes do Comité acerca da importância dos trabalhos da Primeira Sessão em Comité e algumas reflexões finais.

Finalmente foi aprovada uma moção de encerramento, concluindo-se os trabalhos da Sessão de 20 de outubro.

\section{Comité 3 - Trabalho Desigual? Novas} Formas de desigualdade e a organização do
trabalho

Abertura da Sessão

TERESA MANECA LIMA (Secretária do Comité 3)

A secretária do Comité, Teresa Maneca Lima, deu as boas vindas a todos/as os/as 
delegados/as participantes no Comité 3 e procedeu à apresentação da agenda de trabalhos. Em seguida, explicitou o regulamento interno e o modus operandi específico do Comité.

Procedeu-se à eleição dos seguintes cargos:

- Presidente da Mesa, entre os/as delegados/as representantes do Governo. Por unanimidade foi eleita Yasmin Góes, estudante de mobilidade na Faculdade de Direito da Universidade de Coimbra e membro da Secção de Defesa dos Direitos Humanos da Associação Académica de Coimbra (AAC).

- Vice-presidente em representação dos empregadores. Por unanimidade foi eleita Joana Carvalho Silva, aluna do $3 .^{\circ}$ ano da Licenciatura em Gestão, da Faculdade de Economia da Universidade de Coimbra.

- Vice-presidente em representação dos trabalhadores. Por unanimidade foi eleito António Dias de Oliveira Neto, mestre em Direitos Humanos pela Universidade Tiradentes e doutorando em Ciências Jurídico-Filosóficas na Faculdade de Direito da Universidade de Coimbra.

A presidente da mesa, Yasmin Goés, assumiu os trabalhos do Comité.

\section{Discurso da Presidente do Comité 3}

YASMIN GÓES (Presidente do Comité 3)

Boa tarde,

Caros colegas de mesa, senhoras e senhores delegados.

É com imenso gosto que estou aqui perante a todos para participar deste importante evento. Espero poder corresponder às vossas expectativas no decorrer desta conferência como Presidente deste Comité.

Sabemos que a diversidade de perspetivas de observação e descrição de uma sociedade gera problemas distintos a partir de um mesmo evento. Tais efeitos da divergência entre descrição geram impactos diferentes na dinâmica estatal de cada sociedade, sobretudo no que se relaciona ao trabalho e as novas formas de desigualdade após a globalização.

Em várias partes do mundo proliferam condições injustas e opressivas para com os trabalhadores. As desigualdades de género, raça, idade, etnia e o aumento da pobreza são realidades que assustam e que devem ser amplamente discutidas. Portugal reconhece que a discordância entre as diferentes partes do mundo agrava a condição daqueles que estão submetidos aos mais diversos regimes de trabalho. Logo, medidas cabíveis e pontuais são necessárias com vista a proporcionar um trabalho digno e sustentável e a assegurar a dignidade humana, a justiça social, igualdade e segurança.

As leis laborais são entendidas como uma aquisição evolutiva, sendo importante não cair no anacronismo, mas perceber que as condições atuais são diferentes das vividas no passado, havendo espaço para mudanças e para a sua regulação. Espero que as propostas resultantes do trabalho deste Comité possam contribuir para um melhor entendimento e uma futura diminuição de novas e velhas formas de desigualdade, bem como o assegurar de assegurar condições de trabalho sustentáveis. É com a pretensão de igualdade e liberdade que poderemos transformar e mudar a precariedade e a desigualdade no trabalho.

Nesta Conferencia Internacional do Trabalho, espero que possamos através das nossas propostas promover a justiça social, os direitos humanos e os direitos no trabalho como forma de manter uma paz sustentável, o progresso e a prosperidade dentro da comunidade internacional, princípios fundamentais à Organização Internacional do Trabalho. Creio que iremos fazer um ótimo 
trabalho na promoção destes valores $\mathrm{e}$ transformá-los em realidades concretas.

Muito obrigada pela vossa atenção.

Findo o discurso, a Presidente da Mesa prosseguiu com a eleição do Comité de Redação do Comité, da qual resultou a seguinte constituição: Daniela Sofia Neto, do grupo dos Governantes; Rita Fernandes, do grupo dos Empregadores; e Maria Madalena Portugal, do grupo dos Trabalhadores.

A Presidente pediu aos peritos do Secretariado para fazerem uma apresentação sobre os trabalhos do Comité, com o intuito de melhor enquadrar o debate geral.

(seguiu-se a apresentação do tema pelos peritos do Secretariado da ConferênciaAlfredo Campos e Dora Fonseca)

\section{Debate Geral}

$\mathrm{O}$ debate geral iniciou-se com a
intervenção do Vice-Presidente, António Dias Neto, do grupo dos Trabalhadores, que enfatizou as desigualdades no mundo do trabalho, as situações de trabalho forçado e escravo, bem como a precariedade e a fraca inclusão social dos Trabalhadores. Uma forma de alterar esta situação é a promoção da cooperação internacional de todos os parceiros sociais (diálogo social internacional).

Seguiu-se uma intervenção da VicePresidente, Joana Carvalho Silva, do grupo dos Empregadores, que mencionou a necessidade de haver uma relação de equilíbrio entre empregadores e trabalhadores, bem como de promover o bem-estar e a qualidade no trabalho. Enfatizou a necessidade de definir o papel do direito do trabalho na relação das novas formas de trabalho.
O delegado do grupo dos Governantes, Jaime Almeida, destacou a importância da relação entre empresas e universidades para a diminuição do desemprego entre os jovens e em determinados cursos e áreas de especialização. Neste sentido, propôs a criação de um Fórum que agregue universidades e empresas; a adaptação dos manuais escolares e dos principais conteúdos programáticos das universidades aos desafios do mercado de trabalho atual, com o objetivo de diminuir o desemprego jovem.

O delegado Gonçalo Duarte, do grupo dos Empregadores, discursou sobre os estágios e a precariedade assistida pelo Estado. Uma forma de resolver esta questão passa por acabar com os estágios e encontrar outros mecanismos que contribuam para a competitividade das empresas, que considerem a flexibilidade como benéfica para os trabalhadores, uma vez que permite constante formação aos trabalhadores e, por conseguinte, maiores oportunidades de emprego.

O delegado Rafael Neves, do grupo dos Trabalhadores, centrou a sua intervenção no contexto internacional da divisão do trabalho e no seu impacto nos direitos do trabalho, salientando que é necessário compreender que, atualmente, as empresas atuam em redes e que isso constitui um desafio à atuação dos sindicatos. Neste sentido, urge a criação de uma plataforma ou fórum para que sindicatos possam partilhar experiências e trocar informações, bem como um maior estímulo à cooperação técnica entre sindicatos (nacionais e internacionais) para a promoção de um projeto de desenvolvimento. Por exemplo, no caso de empresas internacionais que iniciam as suas atividades no continente africano, onde os trabalhadores desconhecem os seus direitos, é importante a existência de uma cooperação internacional entre sindicatos.

A delegada do grupo dos Empregadores, Marina Buendía, discursou sobre o trabalho 
informal e o caso da economia subterrânea, em particular, a sua variação em termos internacionais. Neste sentido, enfatizou a necessidade de atender às diferenças $e$ características específicas dos diversos países na compreensão do trabalho informal.

Maria Raimundo, do grupo dos Trabalhadores, salientou que os estudantes de hoje são os trabalhadores de amanhã e que, por isso, deveria haver um reforço dos estágios como elemento de garantia de experiência prévia à entrada no mercado de trabalho. Os estágios devem ser obrigatórios em todos os cursos, remunerados e com condições dignas. Para que tal seja possível é necessário fortalecer as políticas ativas de emprego para os jovens (estágios) e complementar competências teóricas com valências técnicas.

Fabrício Rodrigues, do grupo dos Governantes, reforçou a ideia dos estágios como forma de ganhar experiência e a disponibilidade do Governo para reforçar os estágios, inclusive durante as licenciaturas, para que os estudantes possam entrar no mercado de trabalho melhor preparados. Neste sentido, propõe que cada licenciatura deve ter um semestre por ano dedicado ao estágio.

Nuno Cardoso, do grupo dos Trabalhadores, destacou a importância de não construir o debate sobre o futuro do trabalho em torno da questão trabalhador versus máquina. Neste sentido, a redução do horário de trabalho pode ser vista como política de criação de emprego, ou a criação de oportunidades de emprego para mais pessoas. Esta medida traz vantagens e oportunidades em termos do lazer e do setor lúdico e apresenta vantagens familiares - tempo para a família.

Gonçalo Duarte, do grupo dos Governantes, reforçou a importância dos estágios como experiência profissional e aquisição de competências, pelo que propôs a inclusão de estágios durante as licenciaturas e o repensar dos seus valores remuneratórios.

Rafael Neves, do grupo dos Trabalhadores, relembrou que a problemática do futuro do trabalho vai além dos estágios. É importante trazer para discussão as diferenças salariais que ainda persistem e que suscitam a necessidade de tomada de medidas de revisão salarial para diminuir gradualmente disparidades no mundo do trabalho.

Mariana Garrido, do grupo dos Governantes, falou sobre a precariedade e a existência de estágios não remunerados; a desadequação entre trabalhos e funções; e o aumento dos recibos verdes. Perante esta situação defendeu a regulação de situações de falsos recibos verde e a fiscalização de situações de estágios não remunerados como forma de evitar a criação de novos empregos. Para resolver esta questão seria preciso limitar as situações de estágios não remunerados e promover um maior diálogo entre o Governo e as universidades.

Gonçalo Duarte, do grupo dos Empregadores, discursou sobre a discrepância salarial entre trabalhadores qualificados e não qualificados e deu o caso da emigração como solução de futuro para muitos jovens. Neste enquadramento, alertou para a necessidade de repensar as tabelas salariais.

Vasco Simedo, do grupo dos Governantes, referiu a inclusão dos jovens no mercado de trabalho, bem como a valorização das qualificações dos jovens. Propôs a criação de um organismo privado que produza estudos e investigação com o objetivo de colaborar com o Governo, com um Conselho de Administração formado por jovens no mercado de trabalho e jovens universitários, para que os conhecimentos teóricos sejam conjugados com as necessidades práticas. Deste modo, os empregadores não gastariam 
dinheiro em formações e o trabalhador sentirse-ia compensado pela formação que tinha.

Wellington Nunes, do grupo dos Empregadores, discursou sobre a necessidade de aquisição de experiência para o desempenho de funções, mas alertou para o fato que nem todos podem ser integrados no mercado de trabalho por via de estágios. Neste sentido, apelou à definição de políticas públicas para aumento de vagas (estágios ou outros modelos de emprego ativo).

Maria Luiza Pacheco, do grupo dos Governantes, salientou que Portugal é dos países com mais desigualdade de género da União Europeia, nomeadamente em termos salariais. As empresas continuam a dificultar o acesso das mulheres a cargos de direção. Como tal, interpelou o grupo dos Empregadores para esclarecerem as responsabilidades das empresas nesta questão.

Carolina Oliveira, do grupo dos Governantes, referiu que o Ensino Superior não deve estar dependente do mercado de trabalho. Há cursos e áreas importantes socialmente, nomeadamente em termos intelectuais e da solidariedade. O que urge é a conjugação da empregabilidade com a promoção do capital cultural e não apenas económico.

Ana Paula Costa, do grupo dos Governantes, enfatizou a necessidade de melhor regular e fiscalizar os estágios e os salários, ao mesmo tempo que demonstrou disponibilidade para dialogar com os representantes dos Trabalhadores, com o intuito de efetivas as mudanças por eles sugeridas.

Rafael Neves, do grupo dos Trabalhadores, interveio para referir que o trabalho deve ser pensado na lógica dos mercados, mas regulando o seu comportamento, realçando que se deve apostar na criação de mecanismos de troca de informação e experiências entre sociedades.
Natália Alves, do grupo dos Governantes, retomou a discussão sobre os estágios e sugeriu o desenvolvimento de parcerias entre governo e empresas para regulamentação e adequação dos estágios, com o objetivo de promover uma maior integração dos estagiários nas empresas.

Mariana Antunes, do grupo dos Governantes, estruturou o seu discurso em torno de questões relacionadas com os contratos a termo incerto, a idade da reforma, discrepâncias salariais, ou seja, as diferenças entre salários médios e mais elevados numa mesma empresa; e a discriminação de género no acesso a determinados cargos. Neste contexto, lançou o desafio de se promover a diminuição do número de contratos a tempo incerto em nome da segurança no emprego; a diminuição da idade da reforma, como medida de inserção de jovens no mercado de trabalho; a diminuição dos salários mais altos e aumento dos salários mais baixos; e a introdução de quotas para a presença de mulheres em determinadas funções e tarefas.

Cesar Cavalcanti, do grupo dos Governantes, discursou sobre as diversas formas de trabalho forçado e propôs $o$ desenvolvimento de medidas para detetar situações em que estas casos existam, bem como para identificar lucros ilegais das empresas gerados pelo trabalho forçado.

Gonçalo Duarte, do grupo dos Empregadores, defendeu os benefícios dos contratos a termo incerto que permitem fazer face às exigências de produção das empresas e levam a que os trabalhadores se esforcem mais e melhor. Neste sentido, propôs a aceitação de alterações na regulamentação deste tipo de contrato, nomeadamente no que concerne à informação da cessação e tempo para informação.

Por fim, Jaime Almeida, do grupo dos Governantes, reforçou o debate de questões relacionadas com a idade da reforma e a 
sustentabilidade da segurança social; a adequação das vagas no ensino superior e a saturação ou não do mercado de trabalho e profissões; e os estágios como elementos fundamentais entre a universidade $\mathrm{e} o$ mercado de trabalho. Neste panorama, defendeu que é necessário discutir como se poderá melhorar o diálogo entre universidades e o mercado de trabalho, atendendo ao número de vagas disponíveis em alguns cursos, nomeadamente aqueles que onde há necessidade de mais profissionais ou viceversa.

Findo o debate geral, foi proposta uma moção de encerramento que, tendo sido aprovada por unanimidade, colocou fim aos trabalhos da Primeira Sessão em Comité da CIT.

\section{Comité 4-O Futuro das Relações de} Trabalho: direito ao trabalho e o direito do trabalho

\section{Abertura da Sessão}

ANDREIA SANTOS (Secretária do Comité 4)

Os trabalhos tiveram início com a apresentação da secretária do Comité, Andreia Santos, dando as boas-vindas aos delegados e delegadas, e explicitando a ordem de trabalhos.

Em primeiro lugar, oficializaram-se os cargos de Presidente e Vice-Presidentes do Comité, com uma breve apresentação biográfica de cada um, seguida da aprovação por parte do comité, daqui resultando a seguinte constituição:

- Ana Sofia São Simão Horta, do grupo dos Governantes, como Presidente. Ana Sofia Horta é aluna do $4^{\circ}$ ano do Mestrado Integrado em Ciências Farmacêuticas; Vice-Presidente da ESN (da International Exchange Erasmus Student Network) de
Coimbra; é Membro do Pelouro das Relações Internacionais da ESN Coimbra e embaixadora SPEAK (um programa linguístico e cultural criado para aproximar pessoas assente numa partilha de línguas e culturas entre migrantes e locais) em Coimbra.

- Joaquim Nolasco Gil, do grupo dos Empregadores, como Vice-Presidente. Joaquim Gil é aluno do $2 .^{\circ}$ ano da Licenciatura em Direito na Faculdade de Direito da Universidade de Coimbra e membro da ELSA (European Law Students Association).

- Elaine Cristina Silva dos Santos, do grupo dos Trabalhadores, como Vice-Presidente. Elaine Santos é Socióloga e Doutoranda em Sociologia na Faculdade de Economia de Universidade de Coimbra, sendo também Professora da Rede Pública em São Paulo.

De seguida, a Presidente tomou a palavra fazendo um breve discurso. No final, foram indicados oficialmente os membros do comité de redação:

- Érica Tatiane Soares Ciorici, do grupo dos Trabalhadores;

- Daniela Reis, do grupo dos Governantes;

- Thaís Ebert Kasper, do grupo dos Empregadores.

De seguida, os experts do Comité, Marina Henriques e Saulo Aristides, procederam à apresentação da temática do comité 4 , a partir de uma síntese do relatório da OIT intitulado "O Futuro do Trabalho".

\section{Debate Geral}

Finalizada esta exposição, deu-se início aos trabalhos do comité com a mesa (Presidente e Vice-presidentes) a seguirem os procedimentos formais. 
Maria Eduarda, do grupo dos Empregadores, iniciou o debate com uma proposta para adoção do tratado vinculativo de proteção dos direitos humanos no trabalho a ser aprovado em Genebra em outubro, defendendo que é interesse dos empregadores aplicar este tratado. Interpelando os representantes do Governo, defendeu a extraterritorialidade, de modo a aplicar a jurisdição do país de origem dos trabalhadores fora do seu território nacional.

O delegado Gabriel, do grupo dos Governantes, defendeu que a função governamental deve ser conciliadora, sugerindo: standards mínimos vinculativos no sentido de resguardar as especificidades de cada país, inclusive culturais (conforme direito do e direito ao trabalho); divisão do ónus entre os parceiros sociais, por forma a que cada um assuma uma parcela de culpa de modo a conciliar os interesses dos insiders e outsiders (jovens principalmente). Mencionou anda a existência de flexibilização que pode ser positiva.

O delegado do grupo dos Trabalhadores, Rafael, enfatizou que urge agir e escrever. A legislação laboral transforma em lei a força coletiva, e essa força agora está na palavra. É necessário reforçar c.122 sobre políticas de emprego quanto ao pleno emprego e livre escolha desse emprego.

No grupo dos Trabalhadores, a delegada Deise, introduziu dois tópicos para debate. No que concerne a flexibilização laboral, a terciarização (outsourcing) significa precarização das relações laborais. Daqui resulta uma crítica às empresas dado que a flexibilização apenas é produtiva e lucrativa para estas. Em segundo lugar, o trabalho produtivo (o trabalho que é efetivamente pago) e trabalho reprodutivo (cuidado dos filhos, doméstico) - trabalho que é gratuito e deveria ser contabilizado como pago. Esta última temática toca a questão da desigualdade de género, devido também à divergência de salários entre géneros.

A delegada Maria, do grupo dos Empregadores, orientou o seu discurso numa tentativa de evidenciar a realidade. Neste sentido, salientou que o trabalho passa por uma grande transformação, não esquecendo a conjuntura económica e os avanços na tecnologia. Contudo, tudo isto pode trazer benefícios para os Empregadores, Governo e Trabalhadores. Por outro lado, evidenciou a necessidade de se proceder a uma adaptação "direito do trabalho da crise", uma vez que o direito do trabalho tem que se adaptar à crise e os direitos têm que ser geridos de acordo com a conjuntura e as empresas.

O delegado Nuno, do grupo dos Governantes, mostrou-se a favor de uma maior rigidez laboral no sentido de uma maior proteção social. Nesse sentido, é necessário que os trabalhadores expressem as suas exigências com o objetivo de alcançar o consenso.

Também do grupo dos Governantes, a delegada Lauren mencionou o grupo de trabalho das Nações Unidas sobre os direitos humanos - o tratado vinculante. Sobre a questão da terciarização, referiu a cartografia do trabalho no mundo globalizado no sentido de proteção dos direitos humanos.

Após estas intervenções, houve uma proposta de suspensão da sessão por $15 \mathrm{~m}$ pela presidente, aprovada por unanimidade.

Retomados os trabalhos tomou a palavra o delegado Patrício, do grupo dos Empregadores que se mostrou contra a rigidez laboral, considerando-a um fator pouco atrativo para o investimento externo. Sugere que as empresas devem ser beneficiadas pelas boas condições de trabalho através de prémios atribuídos, por exemplo, pela OIT (um 
selo/distinção) que funcionaria como marketing também.

Do grupo dos Trabalhadores, a delegada Érica demonstrou preocupações ambientais e defendeu que a sustentabilidade deve apoiarse na alternativa da economia verde, uma vez que este é um interesse comum. Esta intervenção suscitou uma questão que esclareceu que o Ecolabelling já existe, contudo, uma instituição com poder pode alterar/enganar/comprar a autenticidade deste selo.

Pelo grupo dos Trabalhadores, o delegado Davilson realçou o valor do trabalho - o trabalho torna os indivíduos humanos. Manifestou ainda a visão de que existem os exploradores (empregadores) enquanto que o governo adota uma posição de omissão. Levantou também a questão do rendimento, a classe trabalhadora enquanto penalizada pelos empregadores e governantes, bem como a falta de benefícios para os trabalhadores. Em particular, enfatizou o lucro excessivo que coloca em risco o trabalho digno (muitas horas de trabalho). A solução passa por uma justa redistribuição de rendimento e uma reforma fiscal. No que respeita a esta última, não se trata de diminuir os impostos sobre o trabalho, mas de os fazer recair sobre outras instituições.

Do ponto de vista da regulamentação fiscal /reforma tributária, salienta que a legislação está correta, mas o que ainda falta é um maior equilíbrio entre os lucros das empresas e os benefícios dos trabalhadores.

Ainda no grupo dos Trabalhadores, a delegada Lara levantou a questão da flexibilização dado que prejudica os trabalhadores, incidindo sobre a própria essência do direito do trabalho - função do direito do trabalho que protege $o$ trabalhador/parte mais fraca da relação laboral. Por exemplo, a flexibilização das horas extras tem um impacto negativo mesmo no desemprego (dado que mais exploração do mesmo não gera mais emprego). Assinala que houve uma grande transferência de riqueza para os empregadores.

No seio deste debate, a observadora do grupo dos Trabalhadores e sindicalista, Antónia refere que o equilíbrio entre os empregadores e os trabalhadores deve ser promovido pelo governo. Quanto ao Conselho Económico e Social, refere que existe um défice na representação sindical quanto à concertação social - os trabalhadores não estão representados proporcionalmente dado apenas a UGT e a CGTP fazerem parte da concertação social. Neste sentido, é importante reforçar o papel da OIT.

O delegado Rafael, do grupo dos trabalhadores, retomou a questão ambiental e a necessidade de uma maior aposta na supervisão, uma vez que esta não é apenas uma questão de qualidade de vida, mas sim de sustentabilidade da vida humana e do nosso meio ambiente.

Após estas intervenções, a Presidente encerrou as inscrições, seguindo-se os discursos de encerramento da sessão por parte dos Vice-presidentes.

O Vice-presidente do grupo dos Trabalhadores frisou que o trabalho continua a ser central no funcionamento das sociedades, e é necessário combater a precarização crescente.

O Vice-Presidente do grupo dos Empregadores enfatizou que é nocivo entender as relações de trabalho atuais, tendo como referência a realidade dos séculos XIX e XX. Hoje já não é mais a acumulação de capital o máximo ótimo, são outros desafios aqueles que se colocam ao trabalho. A base de resolução destes desafios não deve assentar no confronto entre empregadores e trabalhadores, mas antes no diálogo entre os mesmos. 
Por fim, a Presidente da Mesa propôs uma moção de encerramento dos trabalhos que foi aprovada por unanimidade. (findos os trabalhos nos vários comités as sessões de trabalho em comité foram adiadas até dia 29 de novembro)

\section{Dia 2}

\section{Segunda Sessão de Trabalho dos Comités}

Terça-feira, 29 de novembro de 2016, 14h00

\begin{abstract}
As Sessões de Trabalho dos Comités foram abertas pelos respetivos Presidentes que fizeram um discurso inicial de boas vindas e procederam à abertura dos debates sugerindo a análise das propostas de conclusão dos respetivos comités uma a uma.
\end{abstract}

As propostas de resolução foram analisadas e discutidas até que se chegasse a um consenso sobre as mesmas. No final registaram-se as propostas de conclusão aprovadas por consenso em cada comité.

Findo este processo, e não havendo objeções os trabalhos em comité foram suspensos até dia 30 de novembro às $10 \mathrm{~h} 30$.

\section{Dia 2}

\section{Primeira Reunião de Grupos}

Terça-feira, 29 de novembro de 2016, 18 h00

Reunidos nos seus respetivos grupos Governantes, Empregadores e Trabalhadores - os delegados da CIT partilharam os principais pontos discutidos no seio dos seus comités e a respetiva proposta de conclusão. Foram levantadas algumas questões sobre as mesmas que foram devidamente debatidas e esclarecidas pelos delegados.

\begin{abstract}
Depois da exposição inicial adiou-se a reunião até às 9 h00 de dia 30 de novembro para proposta de emendas e alterações às propostas de conclusão apresentadas.
\end{abstract}

\section{Dia 3}

\section{Segunda Reunião dos Grupos}

Quarta-feira, 30 de novembro de 2016, 9h00 
Os trabalhos da Segunda Reunião de Grupos começaram às $9 \mathrm{~h}$ da manhã. Os delegados reunidos por grupos - Governantes, Empregadores e Trabalhadores - procederam à análise das propostas de conclusão dos Comités da CIT. Depois desta análise os delegados preencheram os formulários de alteração para registarem as emendas, alterações e substituições que consideraram relevantes. Estas alterações foram posteriormente comunicadas em contexto de grupo e entregues ao secretariado para discussão em votação em sede de Comité.

Dia 3

\section{Terceira Sessão de Trabalho dos Comités}

Quarta-feira, 30 de novembro de 2016, 10h30

As Sessões de Trabalho dos 4 Comités da CIT foi aberta pelos respetivos Presidentes que agradeceram aos membros dos Comités de Redação dos Comités pelos seus trabalhos. Em seguida deu-se início ao processo de análise das propostas de alteração das conclusões dos Comités tal como sugeridas pelos grupos da estrutura tripartida da CIT. As propostas de alteração foram analisadas uma a uma e votadas em conformidade.
Finda a análise e votação das propostas de alteração, bem como a adoção de conclusões, os Presidentes dos Comités encerraram as respetivas sessões agradecendo ao secretariado, ao comité de redação, aos membros da mesa e aos delegados dos seus Comités pelo excelente trabalho desenvolvido durante a CIT. Posteriormente, aprovaram-se moções de encerramento que colocaram fim aos trabalhos dos Comités.

\section{Dia 3}

\section{Sessão Plenária de Encerramento da CIT}

Quarta-feira, 30 de novembro de 2016, 15 h00

\section{Abertura da Sessão}

A Presidente

A Presidente da CIT abriu a Sessão Plenária começando por agradecer aos delegados por todo o seu empenho na Conferência e na elaboração/discussão das propostas de conclusão. Seguiu-se a explanação da ordem de trabalhos da Sessão Plenária. Clarificada esta questão procedimental, a Presidente deu início à apresentação das conclusões da Conferência.
Nesse sentido, deu a palavra aos membros da mesa do Comité 1.

ANA CATARINA NOVAIS (Presidente do Comité 1)

A Presidente do Comité 1, Ana Catarina Novais, congratulou os delegados do grupo dos Governantes, pelo trabalho desenvolvido em sede de Comité. Destacou a proposta para a criação de um fundo económico internacional para o trabalho (supervisionado 
pela OIT) e apela a todos os delegados da CIT para que aprovem a resolução da conferência.

JORDANA BIRCK (Vice-Presidente do Comité 1, representante do grupo dos Empregadores)

A Vice-Presidente do Comité 1, Jordana Birck, em representação do grupo dos Empregadores agradeceu aos delegados do seu comité pelo trabalho desenvolvido. Salientou a necessidade de se melhorar a articulação entre governos, empregadores e trabalhadores para promover um trabalho mais digno e o bem-estar das gerações vindouras. Enfatizou igualmente a urgência de redinamizar a economia internacional e de desenvolver uma gestão mais eficiente dos meios de trabalho, condições sine qua non para melhorar o futuro do trabalho.

WU DZI WEN (Vice-Presidente do Comité 1, representante do grupo dos Trabalhadores)

A Vice-Presidente do Comité 1, Wu Dzi Wen, em representação do grupo dos Trabalhadores, começou por cumprimentar a CIT e demonstrar o apreço do grupo dos Trabalhadores pelos trabalhos desenvolvidos no seu Comité. Manifestou, da mesma forma, o seu apoio às conclusões da Conferência e apelou à sua aprovação pela CIT.

A Presidente

A Presidente da CIT deu a palavra aos membros da mesa do Comité 2 para que pronunciassem acerca das conclusões da Conferência.

RAFAELA HENZ (Presidente do Comité 2)

Boa tarde a todos os presentes na primeira simulação da Conferência Internacional do Trabalho realizada em Coimbra.
Nós, membros do comitê "As Novas Tecnologias: Fim do trabalho ou fim do emprego?" tivemos a nossa frente um grande desafio: como pensar o futuro do trabalho face aos avanços tecnológicos e como direcionar o seu desenvolvimento para a produção de maior justiça social e diminuição das desigualdades.

Nossas propostas compreendem medidas que deverão ser tomadas pelos Estados Membros para que sejam garantidas aos trabalhadores, lesados pela a eminente automação de sua área, requalificações e formações contínuas, com o propósito de garantir sua inserção no mercado de trabalho.

Desta forma procuramos garantir mais oportunidades e uma maior mobilidade no espaço do mercado de trabalho, com trabalhadores mais capacitados para as novas formas de tecnologia e as suas exigências.

A sua formação contínua permite que tanto o trabalhador, quanto a empresa beneficiem desta medida, uma vez o primeiro acompanhará as necessidades do mercado de trabalho e o segundo conseguia assegurar que os seus trabalhadores estão preparados para fazer face aos desafios de um mundo globalizado e onde as tecnologias assumem um papel cada vez mais importante.

Propomos igualmente uma maior regulação sobre o processo de automatização das atividades com a finalidade de salvaguardar determinados setores, como os setores do conhecimento e de criatividade onde deve predominar o trabalho humano.

Em função do aparecimento de novas tecnologias, existe o perigo real de muitas áreas laborais serem extintas, porém é necessário que haja um ajustamento sobre aquelas cujo o conhecimento humano é imprescindível e insubstituível. Será necessário tomar medidas para a proteção e alargamento desses setores de forma a garantir sua evolução. 
Propomos que os Estados Membros orientem o uso das novas tecnologias para a diminuição das desigualdades sociais e em particular das desigualdades de gênero.

Visto que as tecnologias podem muitas vezes beneficiar e facilitar o quotidiano das pessoas, elas podem ser também utilizadas para eliminação de barreiras sociais, de forma a gerar maior equidade entre classes e gêneros.

A Presidente do Comité 2 terminou o seu discurso apelando à CIT que aprovasse a resolução da Conferência.

DANIELA SANTOS (Vice-Presidente do Comité 2, representante do grupo dos Empregadores)

A Vice-Presidente do Comité 2, Daniela Santos, representante do grupo dos Empregadores, congratulou os delegados do seu Comité pelo trabalho desenvolvido. Enfatizou as propostas sugeridas pelo seu grupo que englobavam questões tão amplas como o cofinanciamento da formação de trabalhadores, maior incentivo no processo de patentes e da sua atratividade/competitividade, bem como medidas referentes à carga fiscal.

Terminou a sua intervenção com um apelo à CIT para aprovar a resolução da Conferência.

TONY LUCAS (Vice-Presidente do Comité 2, representante do grupo dos Trabalhadores)

O Vice-Presidente do Comité 2, Tony Lucas, representante do grupo dos Trabalhadores, saudou a mesa e delegados da CIT. Expôs, em seguida, as principais propostas do grupo dos Trabalhadores no seu Comité que incluem o controle do ajustamento salarial, um maior financiamento por parte dos governos - incubadoras solidárias -, a criação de novos postos de trabalho, o desenvolvimento de novas tecnologias e proteção dos trabalhos e do meio ambiente.

Por fim, apelou a que a resolução da Conferência fosse aprovada pela CIT.

\begin{tabular}{l} 
A Presidente \\
\hline A Presidente da CIT deu a palavra aos \\
membros da mesa do Comité 3 para que \\
pronunciassem acerca das conclusões da \\
Conferência.
\end{tabular}

YASMIN GÓES (Presidente do Comité 3)

A Presidente do Comité 3, Yasmin Góes, representante do grupo dos Governantes, agradeceu aos delegados do Comité 3, pelos trabalhos desenvolvidos. Mencionou ainda que destes trabalhos, e perante uma realidade alarmante, resultaram medidas para reduzir desigualdades sociais e de género. Por fim, apelou à aprovação da resolução da CIT.

JOANA CARVALHO SILVA (VicePresidente do Comité 3, representante do grupo dos Empregadores)

A Vice-Presidente do Comité 3, Joana Carvalho Silva, representante do grupo dos Empregadores, salientou o papel das empresas no atual contexto socioeconómico. Neste contexto, é necessário enfrentar mudanças, conciliar interesses de empresas e necessidades dos trabalhadores, limitar situações de exploração laboral e precariedade, aumentar os mecanismos de fiscalização e sanção para situações de violação dos direitos do trabalho. Por fim agradeceu os trabalhos dos delegados e apelou à aprovação da resolução pela CIT. 
ANTÓNIO NETO (Vice-Presidente do

Comité 3, representante do grupo dos Trabalhadores)

O Vice-Presidente do Comité 3, António Neto, representante do grupo dos Trabalhadores, cumprimentou a CIT pelo trabalho realizado. Mencionou questões relativas ao futuro do trabalho, à promoção do trabalho digno e à diminuição das desigualdades. Refere que é importante pensar o futuro, mas também os problemas presentes. Desta forma, destaca as propostas do seu Comité no sentido da erradicação do trabalho escravo e da diminuição de desigualdades.

Por fim, apelou à aprovação da resolução da Conferência.

\begin{tabular}{l} 
A Presidente \\
\hline A Presidente da CIT deu a palavra aos \\
membros da mesa do Comité 4 para que \\
pronunciassem acerca da resolução da \\
Conferência. \\
ANA SOFIA HORTA (Presidente do Comité \\
4)
\end{tabular}

A Presidente do Comité 4, Ana Sofia
Horta, representante do grupo dos Governantes, iniciou a sua intervenção com um cumprimento à CIT. Salientou a discussão ativa no seio do seu comité e lamenta não ter havido mais tempo para abordar temas que são importantes. Do debate gerado destacou a questão da formação e requalificação profissional, da supervisão nacional e da relação entre trabalho digno/produtividade/futuro do trabalho. $\mathrm{O}$ seu discurso terminou com um apelo à CIT para que se aprove a resolução da Conferência.

JOAQUIM GIL (Vice-Presidente do Comité 4, representante dos Empregadores)
O Vice-Presidente do Comité 4, Joaquim Gil, representante do grupo dos Empregadores, enfatizou o esforço de todos os delegados do seu Comité e o seu compromisso em alcançar consensos. Manifesta ainda o seu agrado perante as conclusões aprovadas, destacando aquelas que incidem sobre formação e requalificação profissional, selos de qualidade para empresas cumpridoras para com o Estado e para com os seus trabalhadores, e sobre medidas promotoras de uma sociedade funcional, pacífica e em constante progresso. Por fim, apela à CIT que aprove a resolução da Conferência.

ELAINE SANTOS (Vice-Presidente do Comité 4, representante do grupo dos Trabalhadores)

A Vice-Presidente do Comité 4, Elaine Santos, representante do grupo dos Trabalhadores cumprimenta a CIT e orienta a sua intervenção para a exposição de questões relacionadas com os direitos dos Trabalhadores. Termina com um apelo à CIT para que aprove a resolução da Conferência.

Ás intervenções dos membros das mesas dos Comités seguiu-se a intervenção de 12 delegados da CIT - 3 de cada Comité, representando cada um dos grupos da estrutura tripartida - que expressaram o seu apreço pelo trabalho dos delegados dos respetivos comités e recomendaram a todos os delegados da CIT a aprovação das conclusões apresentadas.

\section{Aprovação da resolução da CIT}

Findas as intervenções dos delegados, a Presidente da CIT deu início ao processo de aprovação das conclusões dos Comités. Não havendo objeções, as conclusões da CIT 
foram aprovadas. Em seguida, a Presidente da CIT mandatou o Comité de Redação da Conferência para redigir a resolução final da CIT.

\section{Discursos de Encerramento}

$\bar{O}$ Vice-Presidente (representante do grupo dos Trabalhadores)

O Vice-Presidente da CIT, Alfredo Campos, representante do grupo dos Trabalhadores iniciou a sua intervenção com os devidos cumprimentos aos membros da Conferência que se empenharam num processo intenso de discussão de questões sobre o futuro do trabalho. Salienta ainda o papel dos delegados do grupo dos Trabalhadores nos 4 Comités da Conferência que procuraram sempre alcançar consensos, mas sem nunca aceitarem medidas pouco dignas ou injustas. Destaca como pontos fundamentais da discussão o aumento dos salários, a valorização da negociação coletiva, as novas tecnologias e a redução das jornadas de trabalho. Congratula, em particular, a medida referente ao aumento dos salários mínimos, uma vez que sem rendimentos dignos não existe possibilidade de uma vida digna. Defende que as novas tecnologias devem contribuir para a redução da jornada de trabalho e lamenta que a redução das mesmas para $35 \mathrm{~h}$ semanais não tenha sido aprovada em sede de Comité. Lamenta ainda que persistam muitos desafios e situações que não podem ser aceites, reiterando que os trabalhadores continuarão a lutar por um mundo melhor. Apesar de considerar que a discussão poderia ter ido mais longe agradece, em nome do grupo dos Trabalhadores, a todos os delegados e delegadas da CIT pelo seu trabalho.

$\overline{\mathrm{O} \text { Vice-Presidente (representante do grupo }}$ dos Empregadores)
O Vice-Presidente da CIT, Nuno Teles, representante do grupo dos Empregadores, inicia a sua intervenção com um cumprimento à CIT. Destaca que este foi um longo trabalho, porque implicava a discussão de um tema de longo alcance que teve como ponto de partida o relatório "O Futuro do Trabalho". Este documento contem muitos desafios a que se somam a mais grave crise económica deste a WWII e as transformações que marcam o palco económico e reorganizam a estrutura e as relações laborais. Neste contexto, demonstra a sua satisfação pelo papel central dos empregadores na formulação de conclusões que incluem: uma maior aposta no empreendedorismo, assumindo as PMEs como coluna vertebral do mercado; novas linhas de financiamento para PMEs; colaboração entre universidades e empresas na preparação dos estudantes para o mercado de trabalho; e uma maior flexibilização fiscal para a criação de empregos. Finaliza com a afirmação que apenas através do diálogo tripartido será possível alcançar um futuro do trabalho digno e agradece à CIT pelo seu trabalho.

\begin{tabular}{l}
\hline A Presidente \\
\hline A Presidente da CIT, Joana Ricarte, \\
começa o seu discurso com um \\
agradecimento à CIT e com a menção que os \\
consensos são essenciais para alcançar a \\
justiça e a dignidade dos empregos e dos \\
trabalhadores - um palco onde a estrutura \\
tripartida desempenha um papel fundamental. \\
Destaca que os delegados do grupo dos \\
Governantes demonstraram uma enorme \\
capacidade de dialogar com os seus parceiros \\
sociais por forma a chegar a conclusões sobre \\
desemprego, desigualdades e questões de \\
género, entre tantos outros. Frisa ainda que a \\
resolução da CIT tem um impacto muito \\
significativo no âmbito do centenário da OIT
\end{tabular}


e na formulação de políticas futuras que vão afetar positivamente as gerações vindouras.

Secretário-Geral

O Secretário-Geral da CIT, João Maia, encerrou a sessão com agradecimentos finais e o reconhecimento do excelente trabalho desenvolvido por todos os delegados e delegadas da Conferência.

(posto isto deram-se por encerrados os trabalhos da CIT, realizados em Coimbra a 20 de outubro e 29-30 de novembro de 2016) 